\title{
Article
}

\section{Supplying Compliance: Why and When the United States Complies with WTO Rulings}

\author{
Rachel Brewster $\dagger$ \& Adam Chilton $\uparrow \dagger$
}

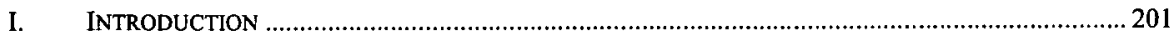

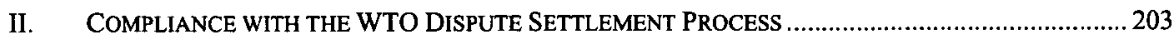

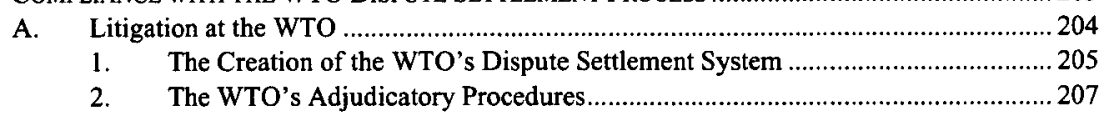

B. Research on Compliance with WTO Decisions .............................................................2210

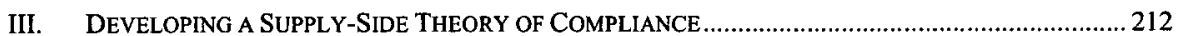

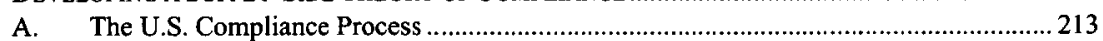

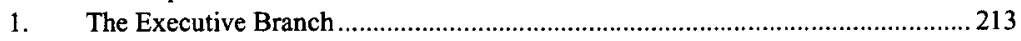

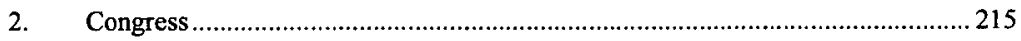

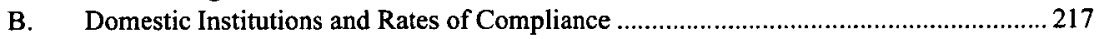

C. Advantages and Limitations of Our Approach.................................................... 218

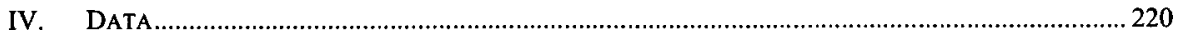

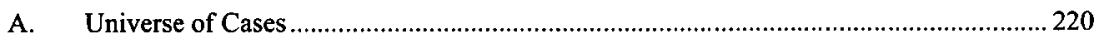

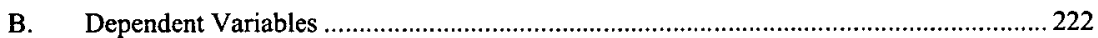

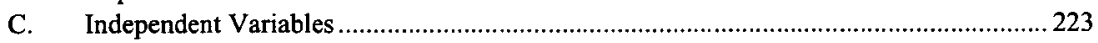

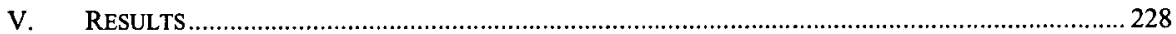

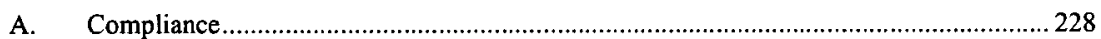

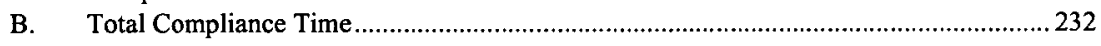

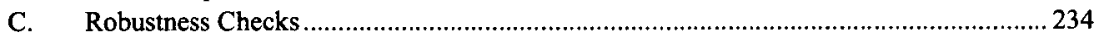

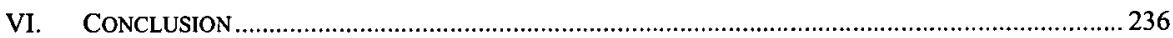

\section{INTRODUCTION}

Consider three examples of American actions to cure WTO violations:

In 1996, the WTO Dispute Settlement Body finds the American ban on imported shrimp caught without turtle-safe nets to be a violation of the General Agreement on Tariffs and Trade (GATT). From 1996 through 1998, the State Department cures the violation by engaging in extensive negotiations with the

$\dagger \quad$ Professor of Law, Duke University.

$+\dagger$ Harry A. Bigelow Teaching Fellow and Lecturer in Law, University of Chicago Law School. We received valuable comments and feedback on earlier versions of this draft during presentations at the 2012 American Society of International Law Research Forum, and the 2012 International Political Economy Society Conference. We also appreciate helpful comments and advice from Curtis Bradley, Anu Bradford, Britt Cramer, Jack Goldsmith, Christina Davis, Tobias Hofmann, Soo Yeon Kim, Beth Simmons, Matthew Stephenson, Ed Swaine, Dustin Tingley, Lesley Wexler, and Mark Wu. 
affected states and by revising agency regulations regarding the certification of acceptable shrimping methods.

In 2000, the World Trade Organization (WTO) Dispute Settlement Body finds the American tax treatment of domestic exports to be a prohibited subsidy. In 2004 , Congress complies with this decision by repealing the relevant sections of the tax code.

In 2003, the WTO Dispute Settlement Body finds the American use of safeguard actions against imported steel to be a violation of the Safeguard Agreement. The President complies by withdrawing the safeguard through an executive order.

In theorizing about international law, much of the focus has been on the "demand-side" of state compliance: how can foreign governments, international institutions, NGOs, or domestic interest groups pressure a specific government to respect its treaty commitments? The national government is modeled as a single transmission belt, aggregating national and international demands and producing a policy outcome. As the examples above illustrate, however, compliance often requires action from different parts of the domestic government.

Although the United States-as a nation-is responsible for any of its violations of international law, who within the state needs to take action to cure a violation depends on the specific measure. Different political actors within the U.S. government can be the "suppliers" of compliance depending on what trade measures need to be altered. As a result, scholars' focus on the demand-side view of compliance has neglected the influence of domestic institutions in the supply policy outcomes and obscured the effects of domestic governmental politics on patterns of compliance with international law.

Our study is one of the first to illustrate how examining the supply-side is necessary to understanding states' compliance behavior. Specifically, we analyze American compliance with legal challenges at the WTO. The WTO treaty agreements include a dispute settlement system that provides third party adjudication of trade law violations, and the WTO has the authority to approve retaliation if a respondent state fails to comply with an adverse judgment. The U.S. government's supply of compliance for WTO disputes varies for different trade issues. For some issues, such as the application of safeguards, the Executive has nearly complete discretion in resolving the dispute. Other issues require executive agencies to amend federal regulations. Finally, other topics, such as agriculture subsidies or intellectual property law, demand legislative action.

We hypothesize that which actor is required to respond to a WTO violation matters because government institutions are differently situated in terms of their decision-making procedures, their engagement in foreign affairs, and their constituencies. These factors make the executive branch more likely to comply (and comply quickly) than Congress. First, it is simply easier for the executive branch to act. Complying with an adverse WTO ruling requires an affirmative change of national policy. All else being equal, the executive branch can act faster than Congress because it has fewer procedural hurdles. Second, the executive branch has a greater interest than Congress in maintaining good interna- 
tional relations on a day-to-day basis. The U.S. government's refusal to comply with an international court's decision may harm the executive branch's effectiveness in foreign affairs-lowering the Executive's perceived job performance-but voters may view the same behavior by members of Congress positively.

To test this theory, we examine how the U.S. government alters national policy in response to the cases initiated within the WTO dispute settlement procedure. To do so, we have compiled the first data set of the policy actions the U.S. has taken in response to other states' requests for dispute settlement consultations. After controlling for important characteristics of the state filing the request and the importance of the affected domestic industry, we are able to demonstrate that who within the government supplies compliance is the best predictor of whether and when the U.S. government complies with WTO rulings. The need for congressional involvement in the compliance process both decreases the likelihood of compliance and delays compliance more than any other factor.

This finding has important implications for international law and international relations theory because it suggests that there may not be a unitary model to explain states' responses to international law. Prior research in international law and international relations studying a state's decision to comply with international law has largely modeled the state as a single, unitary actor. Instead, this work demonstrates that-at least in the context of U.S. compliance with adverse WTO decisions - the decision of whether to comply with international legal obligations varies depending on which domestic political actors are engaged in the policy process. Some institutions are more likely to supply compliance than others. In addition, the structure of the national government can have large, systematic effects on the country's rate of compliance. As such, theoretical approaches that treat states as unitary actors, even when responding to international court judgments against the state, obscure important causal processes that are critical to understanding compliance outcomes.

The discussion proceeds in five parts. Part II discusses dispute resolution procedures at the WTO and previous scholarship that has studied compliance with WTO decisions. Part III examines U.S. compliance procedures before developing the hypothesis that the executive branch should be expected to comply with adverse WTO decisions more often and more quickly than Congress. Part IV describes the data we collected to test this hypothesis, and Part V presents our empirical results. Finally, we conclude by discussing the implications of these results to WTO dispute resolutions specifically and compliance with international law generally.

\section{Compliance with the WTO Dispute Settlement PRocess}

Compliance is a major concern for the study of international law. ${ }^{1}$ In a

1. See generally Beth Simmons, Treaty Compliance and Violation, 13 ANN. REV. POL. SCI. 273 (2010) (surveying research on compliance with international law). In fact, the focus on compliance is so central to the study of international law that perhaps the most cited and analyzed quotation in the 
system without central enforcement where states rely on self-help mechanisms, the states' willingness to comply with international rules that go against their perceived self-interest (immediate or otherwise) is always in question. ${ }^{2}$ Consequently, the field of international law is highly focused on the question of why states comply and how to increase compliance. ${ }^{3}$ This is not only true of international law generally, but international trade law specifically. ${ }^{4}$ This Part explains the WTO dispute resolution system, and then discusses existing scholarship that has sought to explain what drives compliance with WTO decisions.

\section{A. Litigation at the WTO}

The WTO has one of the most well known systems of state-to-state adjudication. ${ }^{5}$ Member states have agreed to give the WTO dispute settlement sys-

field is Louis Henkin's claim that "almost all nations observe almost all principles of international law and almost all of their obligations almost all of the time." LOUIS HENKIN, HOW NATIONS BEHAVE 47 (1979). But see Lisa Martin, Against Compliance, in INTERDISCIPLINARY PERSPECTIVES ON INTERNATIONAL LAW AND INTERNATIONAL RELATIONS: SYNTHESIZING INSIGHTS FROM INTERDISCIPLINARY SCHOLARSHIP 591-92 (Jeffrey L. Dunoff \& Mark Pollack eds., 2013) (arguing that although compliance is one of the primary topics of study by international relations scholars, the focus on it is misplaced).

2. See, e.g., George W. Downs, David M. Rocke \& Peter N. Barsoom, Is the Good News About Compliance Good News About Cooperation?, 50 INT'L ORG. 379, 380 (1996) (arguing that evidence of compliance with international law may be due to selection effects). For a brief overview of why compliance with international law does not always occur efficiently, see ERIC A. POSNER \& ALAN O. SYKES, ECONOMIC FOUNDATIONS OF INTERNATIONAL LAW 127-29 (2013).

3. For an overview of social science research focused on compliance with international law, see Emilie M. Hafner-Burton, David G. Victor \& Yonatan Lupu, Political Science Research on International Law: The State of the Field, 106 AM. J. INT'L L. 47, 88-94 (2012). For examples of empirical scholarship examining compliance with international law, see BETH SIMMONS, MOBILIZING FOR HUMAN RIGHTS: INTERNATIONAL LAW IN DOMESTIC POLITICS (2009) (investigating whether states comply with international human rights treaties); Xinyuan Dai, Why Comply? The Domestic Constituency Mechanism, 59 INT'L ORG. 363, 364 (2005) (investigating how domestic politics drives compliance with international environmental agreements); Michael G. Findley, Daniel L. Nielson \& J.C. Sharman, Using Field Experiments in International Relations: A Randomized Study, 67 INT'L ORG. 657 (2013) (evaluating whether private firms offering business incorporation services comply with international law); Christopher F. Gelpi \& T. Camber Warren, When Preferences and Commitments Collide: The Effect of Relative Partisan Shift on International Treaty Compliance, 63 INT'L ORG. 341 (2009) (evaluating how domestic political factors influence compliance with international agreements); Oona Hathaway, $D o$ Human Rights Treaties Make a Difference?, 111 YALE L.J. 1935 (2002) (studying compliance with international human rights agreements); Daniel W. Hill, Estimating the Effects of Human Rights Treaties on State Behavior, 72 J. POL. 1161 (2010) (analyzing whether states comply with international human rights treaties); James D. Morrow, When Do States Follow the Laws of War?, 101 AM. POL. SCI. REV. 559 (2007) (studying compliance with the laws of war); Beth A. Simmons, International Law and State Behavior: Commitment and Compliance in International Monetary Affairs, 94 AM. POL. SCI. REV. 819 (2000) (studying compliance with international monetary law); Benjamin A. Valentino, Paul K. Huth \& Sarah Croco, Covenants without the Sword: International Law and the Protection of Civilians in Times of War, 58 WORLD POL. 339 (2006) (studying compliance with the laws of war); and Jana von Stein, Do Treaties Constrain or Screen? Selection Bias and Treaty Compliance, 99 AM. POL. SCI. REV. 611 (2005) (questioning previous research on compliance with international treaties). For a discussion of many of the difficulties of studying compliance using observational methods, see Adam Chilton \& Dustin Tingley, Why the Study of International Law Needs Experiments, 52 COLUM. J. TRANSNAT'L L. $176(2013)$.

4. For a review of empirical scholarship on international trade law, see Gregory Shaffer \& Tom Ginsburg, The Empirical Turn in International Legal Scholarship, 106 AM. J. INT'L L. 1, 30-35 (2012). See also infra Section II.B.

5. For a short overview of the WTO dispute resolution process, see POSNER \& SYKES, supra note 2, at 281-87. For a thorough treatment of WTO dispute settlement procedures, see DAVID 
tem broad and mandatory jurisdiction over trade disputes. In addition, member states are expressly prohibited from undertaking countermeasures until the WTO determines that there is a breach of trade rules and sets the limits on the level of permissible retaliation. This Section first briefly discusses the development of this adjudicative institution, including why the U.S. government pushed for the creation of rule-based dispute resolution. It then reviews the procedural rules governing WTO dispute resolution and the application of retaliatory measures.

\section{The Creation of the WTO's Dispute Settlement System}

Negotiated as part of the Uruguay Round of GATT negotiations, the WTO's Dispute Settlement Understanding (DSU) was designed to address governments' dissatisfaction with the GATT regime's dispute resolution process. The GATT formally included a dispute resolution system, but it functioned on a consensus basis, which allowed respondent states to slow down the adjudication and block unfavorable rulings. ${ }^{6}$ Interestingly, the United States was one of the states that spearheaded the proposal for a stronger dispute resolution system in international trade. ${ }^{7}$ The United States had long complained that the GATT dispute resolution procedures were flawed because they precluded the ability to threaten sanctions against states that breached trade rules. ${ }^{8}$ Given the limits of GATT adjudication, the U.S. government developed a practice of unilaterally sanctioning states it judged to be in violation of trade rules. ${ }^{9}$ This practice was very controversial with its trading partners, who argued that the United States was overly aggressive in its interpretation of trade law and the level of sanctions it applied. ${ }^{10}$ In particular, the European Community and the Japanese government demanded that the United States cease this practice. Neither the European governments nor the Japanese government were enthusiastic about creating a more "rule-based" dispute resolution system, as compared to the more "diplomacy-based" GATT system, but were willing to consider such

Palmeter \& Petros C. MAVRoIdis, DisPute SeTtlement IN THE WORLd Trade Organization: Practice and Procedure (1999); ERnSt-Ulrich PetersmanN, THE GatT/WTO Dispute SETTLEMENT SYSTEM: INTERNATIONAL LAW, INTERNATIONAL ORGANIZATIONS AND DISPUTE SETTLEMENT (1997); and JEFF WAINCYMER, WTO LitigATION: PROCEDURAL ASPECTS OF FORMAL DISPUTE SETTLEMENT (2002).

6. See PALMETER \& MAVROIDIS, supra note 5, at 6-11. The GATT system of dispute resolution changed in significant ways between the GATT's creation in 1947 and its effective end with the entry into force of the World Trade Organization in 1995. For an excellent review of the evolution of GATT adjudication and government compliance with panel rulings, see generally ROBERT HUDEC, ENFORCING INTERNATIONAL TRADE LAW: THE EVOLUTION OF THE GATT LEGAL SYSTEM (1993) (tracing the development of GATT law).

7. See John H. Barton et al., The Evolution of the Trade Regime: Politics, Law, AND ECONOMICS OF THE GATT AND THE WTO 69 (2006); Rachel Brewster, Rule-Based Dispute Resolution in International Trade Law, 92 VA. L. REV. 251, 251-52 (2006).

8. See BARTON ET AL., supra note 7, at 69; JOHN CROOME, RESHAPING THE WORLD TRADING SYSTEM: A HISTORY OF THE URUGUAY ROUND 149 (1995); Rachel Brewster, The Remedy Gap: Institutional Design, Retaliation, and Trade Law Enforcement, 80 GEO. WASH. L. REV. 102, 108 (2011).

9. Jagdish Bhagwati, Aggressive Unilateralism: An Overview, in AGGRESSIVE UNILATERALISM: AMERICA'S 301 TRADE POLICY AND THE WORLD TRADING SYSTEM 1-2 (Jagdish Bhagwati \& Hugh T. Patrick eds., 1990).

10. See Brewster, supra note 8, at 108-09; CROOME, supra note 8, at 147-51. 
an institution if it limited states' ability to act unilaterally. ${ }^{11}$

The WTO's dispute settlement system emerged as a compromise between these positions. Fulfilling American demands, the new adjudicatory system would be mandatory, operate on strict timelines, and be capable of authorizing retaliation in response to breaches of trade rules. The new system would also prohibit unilateral action, the condition imposed by the European and Japanese governments. WTO members would not be legally permitted to respond to a perceived violation of trade rules until the WTO system had finished its adjudicatory process and had authorized retaliation.

As a matter of domestic politics, a stronger dispute resolution system for the global trade regime was a longstanding American priority. Congress had specifically instructed the president to seek "more effective and expeditious dispute settlement mechanisms" in the Uruguay Round negotiations in order to enforce U.S. trade rights. ${ }^{12}$ Nonetheless, members of Congress were not entirely satisfied with the new WTO dispute resolution system when the Uruguay Round Agreements were submitted to the House and the Senate for ratification. Legislators recognized that the new adjudicatory mechanisms would bind them, as well as other states, to WTO interpretations of trade rules. As such, many legislators were concerned that trade rules would restrict American sovereignty. ${ }^{13}$ Members of Congress ultimately accepted the dispute resolution mechanism as part of the package of trade benefits and concessions that the new WTO treaty offered. ${ }^{1}$

Agreeing to the dispute resolution system, however, did not make U.S. compliance with WTO adjudicatory decisions a foregone conclusion. The Dispute Settlement Understanding itself does not demand that states comply with WTO adjudicative rulings. Compliance is the "preferred" option, but ultimately states can maintain their policies that breach the trade rules and simply accept retaliatory actions from injured states. ${ }^{15}$ Thus, U.S. policymakers recognized that non-compliance with WTO rulings would always be an option, although perhaps a costly one. Agreement to the WTO dispute resolution system restrict-

11. See Brewster, supra note 8, at 108-09.

12. See Brewster, supra note 7, at 278-79.

13. Id. at 279. Senate Minority Leader Robert Dole offered legislation that would offer an "escape" from adverse WTO rulings. The legislation called for the creation of a commission of federal judges who would evaluate whether the WTO system had exceeded its interpretative authority in any case the United States lost. If the panel found that the WTO system had overstepped its bounds, any legislator could propose a resolution that the United States withdraw from the WTO Agreements. Senator Dole's proposal ultimately did not gain legislative support, but the remedy-that members of Congress propose legislation demanding that the United States exit the WTO-is always a policy option regardless of whether WTO dispute resolution system exceeds its delegated authority. However, the U.S. government's decision of whether to withdraw from the WTO will necessarily entail a broader analysis of the costs and benefits of membership as well as the likelihood that a threat of withdrawal could prompt desired reforms. For an analysis of the Dole legislation, see Gary N. Horlick, WTO Dispute Settlement and the Dole Commission, 29 J. World TRADE 45, 46 (1995); and Gary R. Saxonhouse, Dispute Settlement at the WTO and the Dole Commission: USTR Resources and Success, in ISSUES AND OPTIONS FOR U.S.-JAPAN TRADE POLICIES 363 (Robert M. Stern ed., 2002).

14. See Brewster, supra note 7, at 279-82 (discussing congressional approval of the WTO Agreements under "Fast-Track" voting rules).

15. Warren F. Sykes \& Alan O. Sykes, The Economic Structure of Renegotiation and Dispute Resolution in the WTO/GATT System, 31 J. LEGAL STUD. 179 (2002). 
ed the government's unilateral enforcement of trade rules, but did not require compliance with all adverse decisions. The decision of whether to change domestic policy to abide by WTO rules remained a matter of domestic politics.

\section{The WTO's Adjudicatory Procedures}

In the Dispute Settlement Understanding (DSU), the member states of the WTO created a quasi-judicial system that granted the Dispute Settlement Body (DSB) compulsory jurisdiction over member states' disputes. ${ }^{16}$ If one member alleges that another member is violating its WTO trade obligations, the injured member can bring its complaint to the DSB. ${ }^{17}$ If a member files a formal complaint, the parties are required to engage in consultations to attempt to settle the dispute for at least sixty days. ${ }^{18}$ If consultations fail, the DSB begins the two stage adjudicative process. The parties can mutually agree to suspend or end the case at any point in the process. ${ }^{19}$

The first stage includes a "trial" phase where a panel of ad hoc arbitrators, chosen by the parties, hears evidence from both parties and issues a ruling. ${ }^{20}$ One or both of the parties can appeal the arbitrators' decision on issues of law to the Appellate Body. ${ }^{21}$ If the panel decision is not appealed, then the DSB

16. See Understanding on Rules and Procedures Governing the Settlement of Disputes, art. 1, Apr. 15, 1994, Marrakesh Agreement Establishing the World Trade Organization, Annex 2, 1869 U.N.T.S. 401[hereinafter DSU]. The DSB consists of all of the member states of the WTO. See id. art. 3(10). The DSB grants requests for a panel hearing and adopts the decision of the arbitrators or the Appellate Body by reverse consensus. Reverse consensus means that the panel is authorized and the report is adopted unless no state--including the state that is requesting the panel or has won the legal casesupports the motion. See id. art. 17(14); see also PALMETER \& MAVROIDIS, supra note 5, at 61 ("Under the WTO, the GATT consensus requirement is reversed: consensus in the WTO is required to reject, rather than to adopt, the report."); WAINCYMER, supra note 5, at 718 ("Appellate Body reports are to be adopted by the DSB and unconditionally accepted by the parties to the dispute unless the DSB decides by consensus against.").

17. WAINCYMER, supra note 5, at 132-33. Technically, there can be either a violation of the WTO agreements or a "nullification or impairment" of the complaining member's benefits under the agreement. We use the term "violation" to refer to both for ease of exposition. The DSU gives the DSB compulsory jurisdiction for all disputes concerning the WTO Agreements included in Annex 1. See DSU, supra note 16, art. 1(1). There are some WTO Agreements over which the DSB does not have jurisdiction. See PALMETER \& MAVROIDIS, supra note 5, at 19 (citing Report of the Panel, CanadaAdministration of the Foreign Investment Review Act, 1 1.4, L/55D4 (July 25, 1983), GATT B.I.S.D. (30 ${ }^{\text {th }}$ Supp.) at $\left.140,141(1984)\right)$.

18. DSU, supra note 16, art. 4(7). See PALMETER \& MAVROIDIS, supra note 5, at 66 ("[T]he complaining Member may not ask for a panel until 60 days have elapsed from the date of the original request, unless the parties agree that further consultations would not be productive.").

19. DSU, supra note 16, art. 12(12). The panel may suspend its work at the request of the parties for up to twelve months. If after twelve months the work of the panel is still suspended, the "authority for the establishment of the panel shall lapse." Id.

20. See generally DSU, supra note 16, art. 8 (setting forth the terms of reference of a panel). The panels are normally comprised of three individuals. See PALMETER \& MAVROIDIS, supra note 5, at 68-69. The panelists are typically either former members of delegations to the WTO that were not from one of the countries to the present dispute or academics. Id. In certain conditions, the panel may consist of five members. Id. Additionally, a special provision has been included within the rules of the DSU so that when a developing country is a party to a dispute, it may request that at least one member of the panel be from a developing country. See DSU, supra note 16, art. 8(10).

21. See DSU, supra note 16, art. 17(6) ("An appeal shall be limited to issues of law covered in the panel report and legal interpretations developed by the panel."). 
votes to adopt reports based on a "reverse consensus" rule. ${ }^{22}$ That is, unless there is a consensus in the DSB to reject the panel's report, the report is adopted. ${ }^{23}$ As of this writing, the DSB has never failed to adopt a report using the reverse consensus rule and DSB adoption of reports is generally considered to be a near "automatic" process. ${ }^{24}$

If the panel decision is appealed, then the case is referred to the Appellate Body, a standing body of seven members, who hear appeals in groups of three. $^{25}$ The Appellate Body hears appeals only on questions of law ${ }^{26}$ and will amend the reasoning of the panel if it finds that the panel erred in its interpretation of the WTO Agreements. ${ }^{27}$ The Appellate Body's report is also adopted by the DSB on a reverse consensus basis. ${ }^{28}$ If the adopted report finds that the respondent state is in breach of its WTO obligations, the DSB will recommend that the respondent state bring its measures into compliance with the WTO Agreements within a reasonable period of time-typically twelve to fifteen months. ${ }^{29}$

The adoption of the panel or Appellate Body report is often not the end of the litigation process for specific trade disputes. Members are increasingly engaging in "compliance proceedings" after the initial adjudication. ${ }^{30}$ These proceedings address the question of whether the respondent state's changes to the challenged policy are sufficient to cure the violation. ${ }^{31}$ If the complaining gov-

22. See DSU, supra note 16, art. 16(4) (noting that a report shall be adopted "unless a party to the dispute formally notifies the DSB of its decision to appeal or the DSB decides by consensus not to adopt a report").

23. WAINCYMER, supra note 5, at 632 . For more information on "reverse consensus" requirement in the WTO, see sources cited supra note 16.

24. See, e.g., Judith Goldstein \& Richard Steinberg, Negotiate or Litigate? Effects of the WTO Judicial Delegation on U.S. Trade Politics, 7 L. \& CONTEMP. PROB. 257, 266 (2008) (explaining that adoption of panel reports is almost assured because the prevailing party in the dispute would have to agree to block the ruling due to the reverse consensus rule, which is incredibly unlikely to happen).

25. See DSU, supra note 16, art. 17(1). A three-judge panel of Appellate Body members hears the appeal. The WTO Agreements have no provision for the Appellate Body to sit en banc. Appellate Body members serve for a four-year term that may be renewed by the membership once. For more information on the composition of the Appellate Body, see WAINCYMER, supra note 5, at 706-07.

26. DSU, supra note 16, art. 17(6). See generally WAINCYMER, supra note 5, at 697-98 (describing Appellate Body jurisdiction).

27. DSU, supra note 16, art. 17(13). For more information on the nature of an appeal in the DSU, see WAINCYMER, supra note 5, at 703-05. See also PALMETER \& MAVROIDIS, supra note 5, at 135-52 (describing confidentiality and burden of proof in DSU proceedings). For a critical evaluation of the DSU Appellate Body, see Petros C. Mavoidis, License to Adjudicate: A Critical Evaluation of the Work of the WTO Appellate Body So Far, in TRADE DISPUTE AND THE DISPUTE SETTLEMENT UNDERSTANDING OF THE WTO: AN INTERDISCIPLINARY ASSESSMENT 73 (2009).

28. See Maroidis, supra note 27, at 73 ("An Appellate Body report shall be adopted by the DSB and unconditionally accepted by the parties to the dispute unless the DSB decides by consensus not to adopt the Appellate Body report within $\mathbf{3 0}$ days following its circulation to the Members.").

29. See DSU, supra note 16, art. 21(3) (determining what constitutes a "reasonable period" for implementation of a DSB report is a complicated issue under WTO). For a discussion of the issue, see WAINCYMER, supra note 5, at 648-59.

30. See William J. Davey, Compliance Problems in WTO Dispute Settlement, 42 CORNELL INT'L L.J. 119, 125 (2009) (explaining that compliance proceedings are frequently used as a tactic to delay implementation of DSB reports).

31. These proceedings are governed by DSU Article 21(5). For a discussion of compliance proceedings, see PETER VAN DEN BOSSCHE \& WERNER ZDOUC, THE LAW AND POLICY OF THE WORLD TRADE ORGANIZATION 293-95 (2013). 
ernment believes that the violation has not been cured, then it can request a compliance panel (an Article 21(5) panel) to evaluate whether the respondent state's actions sufficiently addressed the concern. ${ }^{32}$ Like the merits panel report, either party can appeal the compliance panel report to the Appellate Body. ${ }^{33}$ The DSB adopts these reports on a reverse consensus basis. ${ }^{34}$

The second stage of the litigation process is the remedy stage. If a respondent state fails to cure violations of WTO rules within the reasonable period of time set out by the DSB, then the complaining state can request that the DSB authorize it to suspend trade concessions to the respondent state. ${ }^{35}$ The respondent state can request a panel to arbitrate the maximum extent and the possible forms of the suspension. ${ }^{36}$ The parties cannot appeal this ruling. ${ }^{37}$ The DSB implements the panel's ruling by authorizing the complaining government to suspend concessions up to the level determined by the panel. ${ }^{38}$

The retaliation does not make the complaining party whole. The ability to suspend benefits is often economically costly to the state (i.e. raising tariff levels can be expected to harm the economies of the complaining and the respondent state although some political benefits may accrue). ${ }^{39}$ In addition, the remedy offered by the WTO is only prospective. ${ }^{40}$ The retaliation authorized by the DSB (and determined by the panel) is based on the complaining state's current level of injury from the respondent state's policy, meaning the complaining state cannot retaliate for any loss of benefits from the violating policy that occurred before the remedy panel's hearing. This is true even if the respondent state maintained the policy well after the DSB's reasonable period of time to comply with the rule expired. This system creates an incentive for respondent states to drag their feet and extend the litigation process for as long as possi-

32. A compliance proceeding can be initiated by either party to the initial dispute. See Appellate Body Report, United States-Import Prohibition of Certain Shrimp and Shrimp Products, $7 \uparrow$ 152, 153(b), WT/DS58/AB/RW (Oct. 22, 2011).

33. See VAN DEN BOSSCHE \& ZDOUC, supra note 31, at 295.

34. Id.

35. See, e.g., WAINCYMER, supra note 5, at 675-79 (analyzing Article 22 of the DSU). See generally DSU, supra note 16, art. 22 (discussing compensation and suspension of concessions). The authorization is specific to the complaining state (or states, if there is more than one complaining party). Third parties to the litigation (or other states that are injured by the respondent's violation) are not permitted to suspend trade benefits. See PALMETER \& MAVROIDIS, supra note 5, at 169.

36. DSU, supra note 16, art. 22(3). Article 22(3) discusses when different forms of retaliation are permitted. Sectoral retaliation refers to the sectors in the GATS and TRIPS agreements (all goods are considered to be in the same sector under the GATT). "Across agreement retaliation" refers to complaining state actions that withdraw benefits in agreement (GATT, GATS, or TRIPS) other than the one in which the violation existed. See PALMETER \& MAVROIDIS, supra note 5, at 169-71.

37. See DSU, supra note 16, art. 22(7); see also PALMETER \& MAVROIDIS, supra note 5, at 171.

38. PALMETER \& MAVROIDIS, supra note 5, at 171-72.

39. See Adam S. Chilton \& Ryan W. Davis, Equality, Procedural Justice, \& the World Trade Organization, 7 INTERCULTURAL HUM. RTS. L. REV. 105, 145 (2012) (discussing how the economic costs of imposing retaliatory measures may make it undesirable for certain states-particularly developing countries- to impose retaliatory measures under the current rules of the DSU).

40. See Joel P. Trachtman, The WTO Cathedral, 43 STAN. J. INT'L L. 127, 134 (2007) (arguing that the prospective nature of WTO remedies creates a "perverse [incentive] for violation" because offending states are not required to compensate for losses before the expiration of the reasonable period of time). 
ble. $^{41}$

The nature of litigation at the WTO creates two different measures regarding compliance with the WTO process. The first measure is whether the member state formally comes into compliance at all. This is the more straightforward inquiry of whether the state ultimately decides to alter the policy to conform to WTO legal obligations. The second measure is how long it takes the state to comply. Even if the state ultimately decides to amend its measure, how long the respondent state maintains the illegal policy after the adverse DSB decision (the ruling on the merits) is important in determining the quality of the state's compliance. Because the WTO system only permits a prospective reme$\mathrm{dy}$ at the end of the litigation process, the timing of compliance is particularly important in trade law.

\section{B. Research on Compliance with WTO Decisions}

In the last decade, there has been a growing body of literature trying to explain when and why states comply with adverse decisions from the WTO. ${ }^{42}$ Perhaps the most developed articles within this scholarship examine whether the existence and the design of third-party dispute resolution institutions improve compliance rates or otherwise enhance the effectiveness of the treaty regime. ${ }^{43}$ For instance, Daniel Kono finds that the existence of a dispute resolution panel improves trade liberalization between states but that the form of the panel-whether it is more or less legally binding-does not matter. ${ }^{44}$ Marc Busch and Eric Reinhardt find that the institutional shift from GATT dispute resolution to WTO dispute resolution does not improve compliance rates for GATT issues and does not improve compliance in EU-U.S. disputes. ${ }^{45}$ Eric

41. See Davey, supra note 30, at 125 ("Prospective retaliation gives the losing country an incentive to delay the time of reckoning as long as possible and probably explains the extensive delays in the system ...."); see also Trachtman, supra note 40, at 134-35 (noting that the average period from the establishment of a panel to adoption of the final report exceeds three years).

42. See generally Shaffer \& Ginsburg, supra note 4, at 34-35 (discussing the state of scholarship on compliance with WTO law). For examples of studies examining compliance rates with WTO decisions generally, see ROBERT HUDEC, ENFORCING INTERNATIONAL TRADE LAW: THE EVOLUTION OF THE MODERN GATT LEGAL SYSTEM (1993); Chad Bown, On the Economic Success of GATT/WTO Dispute Settlement, 86 REV. ECON. \& STAT. 811 (2004); and Bruce Wilson, Compliance by WTO Members with Adverse WTO Dispute Settlement Rulings: The Record to Data, 10 J. INT'L ECON. L. 397 (2007).

43. There is a rich literature on the question of whether to initiate a WTO dispute. See, e.g., Christina L. DAvis, Why AdJUdiCATE? ENFORCING Trade RULES IN THE WTO (2012); Christina L. Davis \& Sarah Blodgett Bermeo, Who Files? Developing Country Participation in GATT/WTO Adjudication, 71 J. POL. 1033 (2009); Andrew T. Guzman \& Beth A. Simmons, To Settle or Empanel? An Empirical Analysis of Litigation and Settlement at the World Trade Organization, 31 J. LEGAL STUD. 205 (2002); Thomas Sattler \& Thomas Bernauer, Gravitation or Discrimination? Determinants of Litigation in the World Trade Organization, 50 EUR. J. POL. RES. 143 (2010). Although it is certainly possible-if not probable--that domestic political considerations influence the decision to initiate trade disputes, we do not address issues of initiation here.

44. Daniel Y. Kono, Making Anarchy Work: International Legal Institutions and Trade Cooperation, 69 J. POL. 746, 746 (2007).

45. Marc L. Busch \& Eric Reinhardt, Transatlantic Trade Conflicts and GATT/WTO Dispute Settlement, in TRANSATLANTIC ECONOMIC DisPUTES: THE EU, THE US, AND THE WTO 465, 465-66 (Ernst-Ulrich Petersmann \& Mark A. Pollack eds., 2003); see also Marc L. Busch \& Eric Reinhardt, The Evolution of GATT/WTO Dispute Settlement, in TRADE POLICY RESEARCH 143, 143-45 (John M. Curtis 
Posner and John Yoo argue that the design changes between the GATT and the WTO have decreased compliance rates because more independent adjudicators make decisions that are less acceptable to the disputing parties. ${ }^{46}$ By contrast, Bernhard Zangl argues that the GATT to the WTO shift has increased compliance with rulings on EU-U.S. disputes and intra-OECD disputes. ${ }^{47}$ Scholars also argue that more legal dispute resolution institutions should increase compliance by raising reputational costs on breaching states and lowering the reputational costs of sanctioning for complaining states. ${ }^{48}$

It is notable that all of the current approaches examine compliance questions at the state level. Intrastate variation in compliance levels is not measured even if there are theoretical reasons to expect that various governmental bodies would respond differently to international adjudicative decisions. ${ }^{49}$ In WTOspecific and more general compliance studies, the greatest focus by far is on the demand side of compliance--that is, the pressures on the breaching state from

\& Dan Ciuriak eds., 2003) (attributing the success of the WTO in inducing favorable outcomes to the expanded scope of actionable cases and the propensity of wealthy complainants to win, rather than DSU reforms). Busch and Reinhardt find that the WTO dispute resolution system has an overall higher rate of compliance than the GATT dispute resolution system, but they argue that this is due to the inclusion of the TRIPS and GATS agreements (and the high levels of state compliance with DSB decisions on these agreements) in the WTO. Busch \& Reinhardt, supra, at 143-45, 472-75.

46. Eric A. Posner \& John C. Yoo, Judicial Independence in International Tribunals, 93 CALIF. L. REV. 1, 44-57, 66-67 (2005).

47. Bernhard Zangl, Judicialization Matters! A Comparison of Dispute Settlement Under GATT and the WTO, 52 INT'L STUD. Q. 825, 825-27 (2008).

48. See ANDREW T. GuZman, How International Law Works: a Rational Choice THEORY 9, 33-48 (2008); Kenneth W. Abbott \& Duncan Snidal, Hard and Soft Law in International Governance, 53 INT'L ORG. 421, 427-31 (2000); Laurence R. Helfer \& Anne-Marie Slaughter, Toward a Theory of Effective Supranational Adjudication, 107 YALE L.J. 273 (1997); Alexander Thompson, The Rational Enforcement of International Law: Solving the Sanctions Dilemma, 1 INT'L THEORY 307 (2009). Most scholarship on how best to reform the WTO comes from legal scholars who focus on the remedies available under WTO nules. These recommendations are also pitched at the state level. For example, they include calls to increase the level of retaliation available for breach. See, e.g., Davey, supra note 30 , at 123 . Alternatively, they include calls to introduce damages for both retrospective and prospective damages. See, e.g., Marco Bronckers \& Naboth van den Broek, Financial Compensation in the WTO: Improving the Remedies of WTO Dispute Settlement, 8 J. INT'L ECON. L. 101 (2005); Chilton \& Davis, supra note 39, at 321-22; Gregory Shaffer, How to Make the WTO Dispute Settlement System Work for Developing Countries: Some Proactive Developing Country Strategies 41-44 (ICTSD, Resource Paper No. 5, 2003). They also include calls to allow for the collective application of retaliation. See Joost Pauwelyn, Enforcement and Countermeasures in the WTO: Rules are Rules - Toward a More Collective Approach, 94 AM. J. INT'L L. 335 (2000). Other calls are to allow for tradable countermeasures. See, e.g., Kyle Bagwell et al., The Case for Tradable Remedies in WTO Dispute Settlement, in ECONOMIC DEVELOPMENT AND MULTILATERAL TRADE COOPERATION 395 (Evenett \& Hoekman eds., 2006); Chilton \& Davis, supra note 39, at 323-24; see also Special Session of the Council for Trade in Services, Proposal by Mexico, Negotiations on Improvements and Clarifications of the Dispute Settlement Understanding, TN/DS/W/23 (Nov. 4, 2002). But see Trachtman, supra note 40, at 155-56 (discussing the limitations of proposals to create actionable countermeasures). It is worth noting, however, that there are scholars who have advocated against reforming the remedies available under the DSU. See, e.g., Bryan Mercurio, Why Compensation Cannot Replace Trade Retaliation in the WTO Dispute Settlement Understanding, 8 WORLD TRADE REV. 315 (2009); Jide Nzelibe, The Case Against Reforming the WTO Enforcement Mechanism, 2008 U. ILL. L. REV. 319 (2008).

49. See, e.g., Brewster, supra note 7, at 264-5 (arguing that the United States' willingness to submit to binding arbitration by an international trade court is in part due to the President's desire to gain the upper hand in negotiations with Congress); Judith Goldstein, International Law and Domestic Institutions: Reconciling North American "Unfair" Trade Laws, 50 INT'L ORG. 541, 541 (1996) (arguing that membership in international institutions is a strategy by which domestic political actors are able to further their own interests). 
foreign governments, NGOs, or domestic interest groups to conform its actions to be consistent with international law and how institutional design can maximize this pressure. ${ }^{50}$ The field of international law examines only to a much lesser extent the supply side of compliance-the internal state policy process of curing breaches of international law. The only work that currently incorporates domestic institutions are studies of the influence of domestic courts in enforcing international or supranational judicial decisions. ${ }^{51}$ These studies actively discuss domestic institutions, but decision-making is moved out of the hands of elected officials. In addition, the WTO agreements and DSU rulings are not judicially enforceable under U.S. or EU law, and thus, domestic courts are not an active part of the compliance process with global trade issues in the two largest trading states. 52

\section{DEVELOPING A SUPPLY-SIDE THEORY OF COMPLIANCE}

As the last Part illustrated, discussions of compliance with international trade law (or international law in general) focus on the demand side of compliance, and as a result, treat the state as a unitary actor. ${ }^{53}$ An alternate view of the state-from the supply-side-would focus on the role that different government institutions have on compliance. It is our contention that this emphasis on the supply side rounds out the compliance picture. Government institutions mediate competing policy demands from domestic and foreign groups. This Article views political actors as having unique concerns and different abilities to act, instead of viewing the government as a single transmission belt for interest group pressure. Simply shifting compliance decision between political bodies within the same state can lead to different compliance outcomes. The Article explores this idea by examining U.S. compliance with adverse WTO decisions. In this Part, we first explain the U.S. compliance process, and then develop our argument for why the executive branch should be expected to comply more often and more quickly than Congress. After doing so, we outline the advantages and limitations of examining U.S. responses to WTO decisions to gain insight on the influence of domestic institutions on compliance outcomes.

50. For examples of demand-side examinations of compliance with the WTO, see DAVIS, supra note 43, at 244-56; Krzysztof J. Pelc, Eluding Efficiency: Why Do We Not See More Efficient Breach at the WTO?, 9 WORLD TRADE REV. 629 (2010) (discussing the absence of efficient breach); and Tobias Hofmann \& See Yeon Kim, The Political Economy of Compliance in WTO Disputes (2011) (unpublished manuscript), available at http://sykim.weebly.com/uploads/3/3/4/4/3344542/hofmann kim 2009_- wto compliance.pdf. For examples of studies of compliance that focus on the demand side, see $\bar{X}$ INYUAN DAI, INTERNATIONAL INSTITUTIONS AND NATIONAL POLICIES (2007); Dai, supra note 3; and Simmons, supra note 3.

51. Karen J. Alter, Who are the "Masters of the Treaty"? European Governments and the European Court of Justice, 52 INT'L ORG. 121 (1998); Anne-Marie Burley (Slaughter) \& Walter Mattli, Europe Before the Court: A Political Theory of Legal Integration, 47 INT'L ORG. 41 (1993); Helfer \& Slaughter, supra note 48. 442 (2005).

52. Marco Bronckers, The Effect of the WTO in European Court Litigation, 40 TEX. INT'L L.J.

53. JACK GOLDSMITH \& ERIC A. POSNER, THE LIMITS OF INTERNATIONAL LAW 4-5 (2005) ("[W]e give the state the starring role in our drama."); see also Busch \& Reinhardt, supra note 45 (discussing U.S.-EU disputes); Guzman \& Simmons, supra note 43 (discussing transfer payments between states). 


\section{A. The U.S. Compliance Process}

Given the distribution of powers in the American system, who within the state has the authority to comply with the WTO ruling varies depending on the challenged policy. There are several actors who, for different types of policies, will have the power to comply with WTO law. Two actors, the executive branch and the Congress, are discussed below; ${ }^{54}$ although more can be relevant. $^{55}$

\section{The Executive Branch}

The President alone-that is, not acting through an administrative agency-has the power to comply with some rulings against the United States. Where the President has the independent authority to act, either because it falls within the executive branch's constitutional powers or because of delegated power from Congress, the President can act unilaterally to supply compliance. For instance, the President acting alone can cure disputes regarding safeguard action. ${ }^{56}$ A safeguard is a domestic trade remedy that allows a state to raise tariffs on imports when there is an unexpected surge in imports that injures or threatens to injure a domestic industry. ${ }^{57}$ In previous trade legislation, Congress has delegated to the President the exclusive power to apply safeguard measures and to withdraw them. ${ }^{58}$ For instance, President Bush provided the steel industry with safeguard protection in $2002,{ }^{59}$ and President Obama similarly raised tariffs on imported tires in $2009 .^{60}$ In both instances, the Interna-

54. These are the two primary actors in U.S. trade policy. See, e.g., MiCHAEL K. YouNG, UNITED STATES TRADE LAW \& POLICY 147-48 (2001) ("[U]nder the peculiar U.S. constitutional system, the President and Congress share in some substantial measure the power and authority to formulate U.S. Trade Policy.") (emphasis omitted). It is also worth noting that many U.S. trade policy outcomes are shaped by conflict between the Executive branch and Congress. See WILLIAM H. LASH III, U.S. INTERNATIONAL TRADE REgUlATION: A PRIMER 6 (1998) (describing the "continuing battle between Congress and the Executive branch for primacy in trade matters").

55. Congress and the Executive branch are two leading actors in compliance with international trade law, but other governmental entities can have supporting roles. The U.S. federal courts' interpretation of statutory language or rulings on the limits of agency rule-making can either put the United States in violation of the WTO agreements or can be a source of compliance. Subnational state governments' tax or subsidy programs can also cause and resolve trade complaints. See, e.g., Sarah H. Cleveland, Crosby and the One-Voice Myth in U.S. Foreign Relations, 46 VILL. L. REV. 975, 1006-14 (2001) (discussing Crosby v. Nat'l Foreign Trade Council, 530 U.S. 363 (2000)).

56. See Trade Act of $1974 \S \S 201,301,19$ U.S.C. $\S \S 2251,2411$ (2012). For a discussion of the President's power over safeguard issues, see Brewster, supra note 7, at 268. See also Daniel B. Pickard \& Tina Potuto Kimble, Can U.S. Safeguard Actions Survive WTO Review? Section 201 Investigations in International Trade Law, 29 LOY, L.A. INT'L \& COMP. L. REV. 43 (2007) (discussing how the WTO has struck down safeguard actions taken by the United States).

57. Domestic trade remedies are trade actions imposed by the national authorities of the state. Three major actions are safeguard actions, anti-dumping duties, and countervailing duties. States are not required by the WTO to adopt domestic trade remedy rules, but WTO rules govern the application of these remedies if a state chooses to adopt them. For more information on these three actions, see Understanding the WTO: The Agreements, WORLD TRADE ORG., http://www.wto.org/english/thewto_e/whatis_e/tif_e/agrm8_e.htm (last visited Aug. 8, 2013).

58. See Trade Act of $197 \overline{4} \S 201,19$ U.S.C. $\$ 2251$ (2012).

59. For a brief description, see Benjamin H. Liebman, Safeguards, China, and the Price of Steel, 141 REV. WORLD ECON. 354, 354-55 (2006).

60. See Adam Eisenstein, Free Trade, Tires, and Tariffs: Why Imposing Import Duties Against 
tional Trade Commission-a bipartisan six member independent agency-had recommended that safeguards be imposed, but the President has the final decision on whether to impose the safeguard action and the level of protection to grant. ${ }^{61}$ The decision to withdraw the safeguard is also vested exclusively to the president's discretion. ${ }^{62}$ When President Bush withdrew the steel safeguard measure in 2003, he could do so without the consent of Congress and without an agency determination that protection was no longer warranted. ${ }^{63}$

Other trade issues are handled primarily by administrative agencies. These include anti-dumping and countervailing duty measures, as well as a host of regulations that have international trade effects. For instance, the Commerce Department issues rules regarding the methodology for dumping and countervailing duty determinations that have led to adverse DSB decisions against the United States. ${ }^{64}$ The authorizing statute does not require a specific methodology and the Commerce Department has significant discretion in developing these rules. Here, the most immediate source of compliance is the Commerce Department, which could alter its methodologies through its internal rule-making procedures.

Other administrative agencies can also be the source of violations or compliance. ${ }^{65}$ As discussed in the Introduction, the State Department altered its internal rules for implementing a ban on imports of shrimp caught without turtle-exclusion devices. ${ }^{66}$ The relevant policy-the ban on the import of certain shrimp - was mandated by statute, but the State Department's regulations implementing the statute were the source of the trade violation. ${ }^{67}$ Other federal agencies including the Environmental Protection Agency and the Agriculture Department have also created and cured international trade violation through their rule-making processes. ${ }^{68}$

Finally, the line between agency action and sole executive action can

Chinese Goods is the Wrong Cause of Action for the United States, 20 FED. CIR. B.J. 305, 305 (2011).

61. A majority or tie vote of the International Trade Commission is required before the President can impose a safeguard action. Once the safeguard is authorized, the President has the sole authority to decide whether to impose the safeguard, how high the tariff should be, and what markets to exclude from the safeguard. The President can unilaterally alter or eliminate the safeguard action at any time. See Trade Act of $1974 \S 204,19$ U.S.C. $\S 2254$ (2012).

62. See 19 U.S.C. $\$ \S 2251,2411$.

63. See Brewster, supra note 7, at 269.

64. See GREg MATSEL, AMERICAN TRADE LAWS AFTER THE URUGUAY ROUND 71-75 (1996). It is worth noting that we include a dummy variable for trade remedy cases to make sure that domestic trade remedy issues are not driving our results. For a longer discussion on this issue, see infra text accompanying notes 119-120.

65. For a discussion of the role that executive branch agencies play in U.S. trade policy, see YouNG, supra note 54, at 12-13.

66. See Appellate Body Report, United States-Import Prohibition of Certain Shrimp and Shrimp Products, WT/DS58/AB/RW (Oct. 22, 2001).

67. For a discussion of the case, see Howard F. Chang, Toward a Greener GATT: Environmental Trade Measures and the Shrimp-Turtle Case, 74 S. CALIF. L. REV. 31, 43-47 (2000).

68. See, e.g., Steve Charnovitz, Environment and Health Under WTO Dispute Settlement, 32 INT'L L. 901, 909-10 (1998) (discussing the EPA's role in the U.S.-Gasoline dispute in the WTO) (citing Panel Report, United States-Standards for Reformulated and Conventional Gasoline, WT/DS2/R (May 30, 1997)). 
sometimes be blurred. ${ }^{69}$ The executive branch is structured as a hierarchy. Although agencies are delegated power by the legislature, monitored by congressional committees, and have to comply with rule-making procedures, the President has the power to appoint and dismiss top agency policymakers. Agency heads are members of the President's Cabinet and presumably follow the President's policy lead. ${ }^{70}$ This relationship makes parsing agency action and presidential action difficult. In addition, Presidents are entering into sole executive agreements with foreign governments to alter administrative agency behavior. For instance, the President has entered into international compacts regarding the long-standing Softwood Lumber dispute (addressing countervailing duty issues) $)^{71}$ and controversies involving the methodology for calculating antidumping duties. ${ }^{72}$ As sole executive agreements, these compacts do not need any legislative approval to enter into force. ${ }^{73}$ Sole executive agreements blur the line between executive action and agency action because they involve issues within the agency's policy scope but are addressed in executive agreements. As a result, we group the administrative agencies and sole executive policies into one category of executive branch action. Although we believe that it may be fruitful for future research to explore the differences between executive agencies, this Article focuses on the distinction between the compliance efforts of the congressional and executive branches.

\section{Congress}

When the challenged policy is set by the text of a statute, compliance requires engaging in the domestic statutory process. ${ }^{74}$ Here, the answer to the question of "who complies?" consists of multiple actors: bicameral majorities when there is presidential support of the legislation or veto-proof bicameral majorities when there is not presidential support. What issues require congressional attention is defined by the nature of the trade law allegation and the domestic governance system. ${ }^{75}$ If Congress has previously delegated policy pow-

69. For a general overview of presidential control over the administrative state, see Elena Kagan, Presidential Administration, 114 HARV. L. REV. 2245 (2001) (arguing that there has been a transformation that has turned executive agencies into an extension of the President's policy agenda).

70. But see Jennifer Nou, Agency Self-Insulation Under Presidential Review, 126 HARV. L. REV. 1755 (2013) (arguing that executive branch agencies often have considerable discretion).

71. See generally DAOWEI ZHANG, THE SOFTWOOD LUMBER WAR: POLITICS, ECONOMICS, AND THE LONG U.S.-CANADIAN TRADE DISPUTE (2007) (providing a detailed account of the longstanding U.S.-Canada softwood lumber dispute).

72. See generally Kamal Saggi \& Mark Wu, Yet Another Nail in the Coffin of Zeroing: United States Anti-Dumping Administrative Reviews and Other Measures Related to Imports of Certain Orange Juice from Brazil, 12 WORLD TRADE REV. 377 (2013).

73. See United States v. Belmont, 301 U.S. 324 (1937) (discussing the President's authority to enter into executive agreements with foreign countries); DANIEL C. K. CHOW \& THOMAS J. Schoenbaum, International Trade Law: Problems, Cases and Materials 102 (2d ed. 2013) (discussing the differences between treaties and sole executive agreements).

74. For a discussion of U.S. statutes that have been challenged in the WTO, and thus require congressional action to remedy, see KEVIN C. KENNEDY, INTERNATIONAL TRADE REGULATION: READINGS, CASES, NOTES, AND PROBLEMS 565-66 (2009).

75. See generally YOUNG, supra note 54, at 14-19 (reviewing the role of Congress in U.S. trade policy). 
er to an administrative agency and the agency has issued a ruling that creates the violation, then congressional action is not necessary to cure the violation. By contrast, if the violation requires a change to the statute, then Congress must act directly. ${ }^{76}$ Trade topics that generally need direct congressional action include intellectual property rules, tax law, and agriculture subsidies.

The topics that require congressional action are not necessarily more politically sensitive or considered higher stakes issues. Congress delegates to the executive branch the ability to make determinations concerning sensitive topics, such as relations with foreign nations, "unfair trade" practices that threaten import-competing firms (and local employment), as well as environmental and labor standards. ${ }^{77}$ There generally is a need for direct congressional action when Congress has not delegated implementation of a policy to an agency-as is often the case in intellectual property-or when the existence, not the implementation, of a government policy is challenged. Thus, some very smallstakes issues require congressional action-such as a dispute over a single trademark $^{78}$ - while some high stakes issues-such as disputes over environmental policy ${ }^{79}$ - are delegated to the Executive. In addition, our study controls for the political contributions of the affected industries, which accounts for issues that are politically sensitive because of interest group politics.

The discussion of the domestic government's supply of compliance raises an additional issue that can usefully be addressed here. Compliance with international trade rules can almost always be achieved through a statutory enactment. Except for rare constitutional cases, such as individual rights issues or federalism issues (which rarely arise in international trade), Congress has plenary power over foreign commerce. ${ }^{80}$ Thus, any government act that violates

76. For example, legislation allowing for distribution of anti-dumping duties was successfully challenged by a group of foreign governments before the WTO. See, e.g., Decision by the Arbitrator, United States-Continued Dumping and Subsidy Offset Act of 2000, WT/DS234/ARB/CAN (Aug. 31, 2004). This required congressional action to cure the violation. See KENNEDY, supra note 74 , at 565 . For more information on this case, see Jesse Kalproth, Decision by the Arbitrator-United StatesContinued Dumping and Subsidy Offset Act of 2000: Payback Is for the Byrds: Arbitrator Allows Eight Countries to Sanction the United States for Application of the Byrd Amendment, 13 TUL. J. INT'L \& COMP. L. 401 (2005).

77. For a partial list of specific delegations of authority over trade related issues from Congress to the executive branch, see JAE WAN CHUNG, THE POLITICAL ECONOMY OF INTERNATIONAL TRADE: U.S. TRADE LAW, POLICY, AND SOCIAL COST 101-02 (2006).

78. For example, compliance with the WTO dispute resolution process in the Havana Club Rum case, which is a dispute over a specific trademark, required Congressional Action. See, e.g., Appellate Body Report, United States-Section 211 Omnibus Appropriations Act of 1998, WT/DS176/AB/R (Jan. 2, 2002); Panel Report, United States-Section 110(5) of the US Copyright Act, WT/DS160/R (June 15, 2000). For more information on this case, see Donald R. Dinan, An Analysis of the United States-Cuba “Havana Club" Rum Case before the World Trade Organization, 26 FORdHAM INT'L L.J. 337 (2002); and Emily Taylor, The Havana Club Saga: Threatening More than Just "Cuba Coke," 24 NW. J. INT'L L. \& BUS. 513 (2003).

79. For example, compliance with the WTO dispute resolution process in the Shrimp/Turtle case, which is a dispute over environmental regulations, requires executive branch action. See Appellate Body Report, United States-Import Prohibition of Certain Shrimp and Shrimp Products, WT/DS58/AB/R (Oct. 12, 1998). For more information on this dispute, see Mark Wu \& James Salzman, The Next Generation of Trade and Environment Conflicts: The Rise of Green Industrial Policy (Apr. 2013) (unpublished manuscript), available at www.law.harvard.edu/faculty/facultyworkshops/ wu. faculty.workshop.spring-2013.pdf.

80. See U.S. CONST. art. $1, \S 8, \mathrm{cl} .1$ (specifying that "[t]he Congress shall have Power to lay 
international trade law can be corrected through statutory means. For instance, Congress could amend American anti-dumping rules to prohibit the use of certain methodologies (or anti-dumping duties entirely) even if the Commerce Department refused to amend its internal rules. While this is true, collapsing the existing domestic political system of compliance into the statutory process ignores sources of compliance that may be far easier to achieve than changes to federal legislation. The federal legislative process represents a very high bar in terms of the difficulty in achieving policy change. Significant political capital is necessary to get an issue on the legislative agenda and there are multiple veto points in the legislative process. In addition, to view all compliance as a matter of legislation ignores long-standing governmental practice regarding compliance with international rules.

\section{B. Domestic Institutions and Rates of Compliance}

As we have just explained, which branch of the U.S. government has the authority to comply with adverse WTO decisions varies based on the issue. This does not mean, however, that both the executive branch and Congress should be viewed as equally likely to comply (as unitary actor models assume). Instead, we hypothesize both that the executive branch is more likely to comply, and also that it will do so more quickly.

We hold this view for several reasons. First, the executive branch is uniquely concerned with foreign policy. ${ }^{81}$ Compared to Congress, the executive branch is responsible for maintaining good foreign relations and its per-

and collect Taxes, Duties, Imposts, and Excises"); U.S. CoNST. art. 1, § 8, cl. 3 (specifying that "[t]he Congress shall have Power . . . [t]o regulate Commerce with foreign Nations"); see also LASH, supra note 54, at 1 ("Congress has the plenary authority to regulate foreign commerce . ..."); YouNG, supra note 54, at 25 ("[I]n the field of international economic affairs, significant power has been granted to Congress by the Constitution.").

81. The Executive branch is widely viewed as having special expertise and discretion when conducting foreign affairs. This fact has been recognized by a number of judges, policy makers, and scholars. For example, the United States Supreme Court has recognized the Executive branch's domain in international affairs. See, e.g., Unites States v. Curtiss-Wright Export Corp., 299 U.S. 304, 320 (1936) (referring to the Executive branch as the "sole organ of the federal government in the field of international relations."). There is also an expansive literature in political science on the "Two Presidencies," which essentiaily argues that the executive branch has different powers over foreign affairs and domestic affairs. See, e.g., Brandice CANEs-Wrone, Who Leads Whom: Presidents, Policy, ANd the PUBLIC (2006); B. Canes-Wrone, William G. Howell \& David Lewis, Toward a Broader Understanding of Presidential Power: A Reevaluation of the Two Presidencies Thesis, 70 J. POL. 1 (2008); A. Wildavsky, The Two Presidencies, 4 TRANS-ACTION 7 (1966); Helen V. Milner \& Dustin Tingley, Sailing the Water's Edge: Where Domestic Politics Meets Foreign Policy (2012) (unpublished manuscript), available at http://irworkshop.sites.yale.edu/sites/default/files/milnertingleywatersedge.pdf. Although it is fair to say that the executive branch has a great interest in and control over foreign policy, it is worth noting that there has been a lively debate in legal scholarship over exactly how much deference should be given to the Executive branch. See, e.g., Daniel Abebe \& Eric A. Posner, The Flaws of Foreign Affairs Legalism, 51 VA. J. INT'L L. 507 (2011); Curtis A. Bradley, Chevron Deference and Foreign Affairs, 86 VA. L. REV. 649 (2000); Curtis A. Bradley \& Martin S. Flaherty, Executive Power Essentialism and Foreign Affairs, 102 MICH. L. REv. 545 (2004); Curtis A. Bradley \& Trevor W. Morrison, Presidential Power, Historical Practice, and Legal Constraint, 113 CoLUM. L. REV. 1097 (2013); Derek Jinks \& Neal Katyal, Disregarding Foreign Relations Law, 116 YALE L.J. 1230 (2007); Julian Ku \& John Yoo, Hamdan v. Rumsfeld: The Functional Case for Foreign Affairs Deference to the Executive Branch, 23 CONST. COMMENT. 179 (2006); Eric A. Posner \& Cass R. Sunstein, Chevronizing Foreign Relations Law, 116 YALE L.J. 1170 (2007). 
formance is evaluated more based on foreign policy success. While there are foreign relations committees, members of Congress are less engaged in international affairs. Second, domestic institutions have varying capacities to act and act quickly. ${ }^{82}$ The executive branch has fewer veto players than congressional action does. $^{83}$ The president can unilaterally act in some areas of foreign affairs and can form sole executive agreements that regulate some elements of administrative law. ${ }^{84}$ Executive agencies have more complicated procedures for altering regulations and these regulations are subject to legal challenge, but agencies act as a part of the hierarchical structure of the executive branch. By contrast, decision-making in Congress is more difficult. ${ }^{85}$ Bicameralism and super-majority voting rules in the Senate establish barriers to altering status quo policies. $^{86}$

Applied to WTO litigation, this model predicts that compliance will be lower if congressional action is necessary to supply compliance. Congress has fewer interests than the executive branch in having high levels of compliance with international law to maintain good foreign relations. In addition, Congress has a more difficult time acting to change established policies than the executive branch. All else being equal, we expect that the executive branch will comply with adverse WTO decisions more often and in a shorter period of time than Congress will.

\section{Advantages and Limitations of Our Approach}

Before proceeding to the discussion of our data collection and results, it is worth noting that our decision to study the supply side of compliance by focusing on U.S. compliance with adverse DSB decisions has both advantages and limitations. We will briefly discuss both.

An advantage of studying compliance in the WTO setting is the existence of a dispute resolution system with compulsory jurisdiction. This resolves the problem of auto-interpretation in international law: governments will frequently dispute whether a violation of international law exists and, without a third party adjudicator, it is hard to collect an objective sample of "violations." Compulsory jurisdiction also solves a selection bias issue. If dispute resolution is voluntary and the parties only agree to adjudicate "politically easy" cases, then the sample of decisions may be biased (because the "politically hard" cases are never heard). The results of these studies may be overly optimistic in terms of

82. Comparative institutional competency is a widely discussed topic in law and political science. For a brief review, see Adam S. Chilton \& Christopher A. Whytock, Foreign Sovereign Immunity and Comparative Institutional Competency, 163 U. PA. L. REV. (forthcoming 2014). See also NEIL K. KOMESAR, IMPERFECT ALTERNATIVES: CHOOSING INSTITUTIONS IN LAW, ECONOMICS, AND PUBLIC POLICY (1997) (discussing institutional comparisons).

83. See generally KeITH KREHBIEL, Pivotal Politics: A TheORY OF U.S. LawMaking (1998) (discussing veto points in the U.S. political system and their influence on policy making).

84. See generally CURTIS A. BRADLEY \& JACK GOLDSMITH, FOREIGN RELATIONS LAW: CASES AND MATERIALS 160-80 (2011) (reviewing areas where the executive branch has unilateral power over foreign affairs).

85. See KREHBIEL, supra note 83.

86. Id. 
states' willingness to comply with adjudicatory rulings. The WTO's compulsory jurisdiction decreases this selection bias because the respondent state need not agree for the adjudicatory system to proceed. The WTO dispute resolution system additionally has one of the highest caseloads for an international dispute resolution system, so there are a sufficient number of cases to provide a meaningful quantitative analysis.

Of course, our sample of WTO cases may still have problems with selection bias. Some trade disputes may be resolved through diplomatic means before a request for consultation is ever filed at the WTO. If so, then these cases do not become part of our data set. As a result, our data set may be biased in the sense that the dispute has to be difficult enough to resolve that it cannot be handled diplomatically. In addition, some disputes will not involve a sufficient quantity of trade to be worthy of the expense and energy of international litigation. Some states may also not have the financial or legal capacity to meaningfully engage the WTO system, and thus, will engage the dispute resolution system less frequently than states with greater financial and legal capacities. This tendency to avoid WTO litigation may also be heightened when the United States is the respondent state because developing countries may fear a diplomatic backlash to trade litigation. ${ }^{87}$ On the whole, the data set is not free of selection bias concerns, but it provides a good sample of cases involving a variety of trade issues brought by a wide range of complaining states.

Our study also focuses exclusively on the United States as the respondent in WTO litigation. We do so because we are interested in how the domestic institutional source of trade policy influences a state's compliance behavior, and therefore, we must open the "black box" of the state's decision-making. This is a state specific inquiry. We have chosen to look to the United States because it is a frequent party to trade litigation and we are familiar with its trade policy processes. ${ }^{88}$ The inquiry is highly relevant to understanding patterns of trade law adjudication - the United States is one of the most common defendants at the WTO-but this comes with some limitations. Because our study focuses on one governmental structure, it may not be generalizable to all states. In addition, the economic power of the United States may provide its government with a greater capacity to resist international calls for compliance; thus its rates of non-compliance may be higher than in other states. ${ }^{89}$ However, understanding how international law and international adjudicative decisions influence policy in economically powerful states like the United States provides important in-

87. See, e.g., Davis \& Bermeo, supra note 43, at 1035 ("Small developing states may feel constrained from initiating a case against their larger trade partners because they do not anticipate that they will be able to gain concessions or because they fear losing aid or preferential trade.").

88. Other scholars, who have better knowledge of domestic compliance procedures in other states, could conduct similar studies. The domestic supply of compliance with WTO adjudicatory decisions depends on the nation's internal legal rules and delegation of powers to various branches of government. Such a state-by-state analysis requires knowledge of the nation's formal rules as well as its informal government practices.

89. The American dualist legal structure may also give political actors in the U.S. government more domestic legal leeway to resist implementation of international legal rulings. We do not want to emphasize this point too strongly, however, because other more monist states also give political actors greater leeway with regards to international trade obligations. See Bronckers, supra note 48. 
sight into constraining effects of international law.

Finally, it is worth noting that the decision to focus solely on the U.S. response to adverse DSB decisions necessarily means that our study has a small sample size. In fact, there are only thirty-seven observations used in our primary analysis. As a consequence, it is important to caution that future studies that are able to examine a larger sample of cases may produce different results.

\section{DATA}

To test these expectations, we have built an original dataset of disputes filed against the United States in the WTO. ${ }^{90}$ Because our theory makes specific predictions on how the identity of the actor that is required to comply influences whether and when compliance will occur, we have collected a large amount of information on each dispute that has not previously been collected or analyzed by scholars. In this Part, we briefly outline the process we have used to construct the dataset built for our project and explain the coding decisions that we made along the way. First, we outline the universe of cases that is included within our dataset. Second, we discuss the dependent variables used to test our theory. Third, we describe the independent variables that we have collected to test our theory of compliance.

\section{A. Universe of Cases}

The first decision that we made while constructing our dataset is determining which cases to include. We initially limited our analysis to disputes initiated against the United States in the WTO prior to 2012. ${ }^{91}$ As of December 31,2011 , there had been 113 requests for consultations filed with the WTO in which the United States was the respondent. ${ }^{92}$ It would be inappropriate to assume based on this fact, however, that the correct number of observations to look at to test our hypothesis would be 113 cases. This is because the total of 113 cases includes disputes that were consolidated, and cases where the United States prevailed (thus not requiring the United States to have to take subsequent compliance actions). Additionally, in many cases it would be inappropriate to include cases that were settled before litigation was completed. As a result, determining the universe of cases for our study required in-depth classification of all of the requests for consultation with the United States filed at the WTO.

90. All of the replication code and data collected for this project will be made publically available. For a discussion of the importance of releasing replication data, see Allan Dafoe, Science Deserves Better: The Imperative to Share Complete Replication Files (June 18, 2013) (unpublished manuscript), available at https:/www.dropbox.com/s/m111842pjeb5d45/13-05-04\%20science\%20deserves\% 20better.pdf.

91. We made this decision for two reasons. First, by limiting our analysis to cases initiated before 2012 , we were able to analyze cases that had at least some time to work through the DSU process. Second, by limiting our time in this way we were able to ensure that independent variables from external datasets were available for all of the disputes in our dataset. If we were to have analyzed more recent cases, this may not have been possible.

92. See Current Status of Disputes, WORLD TRADE ORGANIZATION, http://www.wto.org/english/tratop_e/dispu_e/dispu_current_status_e.htm (last visited Aug. 9, 2013). 
Given these concerns, we used a three-step process to cull the cases to give us our final universe of cases. First, any disputes that were either consolidated with earlier cases or repeats of earlier cases on the exact topic were turned into a single dispute. For example, United States-Gasoline ${ }^{93}$ brought by Venezuela and United States-Gasoline ${ }^{94}$ brought by Brazil were consolidated into a single observation because they were consolidated during the dispute resolution process. Likewise, United States-Measures Affecting Textiles and Apparel Products ${ }^{95}$ and United States-Measures Affecting Textiles and Apparel Products (II) ${ }^{96}$ were treated the same way because they were both cases brought by the European Union on the same issue. This resulted in 23 cases being removed from the initial 113 disputes. ${ }^{97}$ Second, since the United States is not expected to take steps to comply in disputes that it either won or disputes where litigation is still ongoing, these cases were also removed from the dataset. To identify these cases, we relied on a document produced by the U.S. Trade Representative (USTR) Office that identified cases where the United States "won on the core issue(s)." 98 This resulted in 35 additional disputes being excluded from the dataset.

Third, we excluded cases that were settled without the litigation process being completed. We compiled this list both by relying on the USTR document previously mentioned ${ }^{99}$ and the reported status of cases reported on the WTO website. This resulted in 18 additional cases being removed from our dataset. ${ }^{100}$ After these steps, we were left with 37 cases where the United States did not prevail on the core issue at stake in the dispute that formed the primary universe of cases for our empirical tests. ${ }^{101}$ Table 1 presents a breakdown of the 113 disputes filed with the WTO prior to December $31,2011$.

93. United States-Standards for Reformulated and Conventional Gasoline, WT/DS2 (Consultations Requested on Jan. 24, 1996) (Complaint: Venezuela).

94. United States-Standards for Reformulated and Conventional Gasoline, WT/DS4 (Consultations Requested on Apr. 10, 1995) (Complaint: Brazil).

95. United States-Measures Affecting Textiles and Apparel Products, WT/DS85 (Consultations Requested on May 22, 1997).

96. United States-Measures Affecting Textiles and Apparel Products (II), WT/DS151 (Consultations Requested on Nov. 19, 1998).

97. For a discussion of how consolidated cases and cases brought by multiple complaints were treated for coding, see infra notes 112, 114 and accompanying text. For a discussion of an alternative approach that we took to address these cases, see infra notes 166-168, and accompanying text.

98. U.S. TRADE REPRESENTATIVE, SNAPSHOT OF WTO CASES INVOLVING THE U.S. (2011).

99. Id.

100. We still collected compliance information on all of the cases that were settled, which we used to provide a robustness check to our primary results. See infra text accompanying notes 164-165.

101. The complete list of cases included in our dataset is available in Appendix C. 


\begin{tabular}{|c|c|}
\hline \multicolumn{1}{|l|}{ Table 1: Breakdown of the Universe of Cases } \\
\hline Category of Cases & Total Cases \\
\hline Consolidated or Repeat Cases & 23 \\
\hline U.S. Prevailed on Core Issue / Monitoring in Progress & 35 \\
\hline U.S. Settled / No Longer in Progress ("Settled Cases") & 18 \\
\hline U.S. Did Not Prevail on Core Issue & \\
\hline Dispute Resolved ("Compliant Cases") & 24 \\
\hline Dispute Not Resolved ("Non-Compliant Cases") & 13 \\
\hline Total Cases & 113 \\
\hline
\end{tabular}

\section{B. Dependent Variables}

After establishing our universe of cases, the second task was to determine the relevant dependent variables to test our theory. In our cases, there are two outcomes that we were primarily interested in: (1) whether compliance occurred; and (2) how long it took compliance to occur.

The first task was to determine how to code whether compliance has occurred in a given dispute. Determining how to do so was made easier by a Congressional Research Service report that documents the status of the WTO disputes that the United States has been part of at the end of the year. The report used for our study was published on April 23, 2012. ${ }^{102}$ That report listed 13 cases where the United States is currently not in full compliance with the WTO's decision. ${ }^{103}$ These cases were thus coded as "1" ("non-compliant"),

102. JEANNE J. GRIMMETT, CONG. RESEARCH SERV., RL 32014, WTO DiSPUTE SETTLEMENT: Status of U.S. COMPlianCE IN PENDING Cases (2012).

103. These thirteen cases are: United States-Section 110(5) of US Copyright Act, WT/DS160 (Consultations Requested on Jan. 26, 1999); United States-Section 211 Omnibus Appropriations Act of 1998, WT/DS176 (Consultations Requested on Jul. 08, 1999); United States-Anti-Dumping Measures on Certain Hot-Rolled Steel Products from Japan, WT/DS184 (Consultations Requested on Nov. 18, 1999); United States-Continued Dumping and Subsidy Offset Act of 2000, WT/DS217 (Consultations Requested on Dec. 21, 2000); United States-Continued Dumping and Subsidy Offset Act of 2000, WT/DS234 (Consultations Requested on May 21, 2001); United States-Subsidies on Upland Cotton, WT/DS267 (Consultations Requested on Sep. 27, 2002), United States-Measures Affecting the CrossBorder Supply of Gambling and Betting Services, WT/DS285 (Consultations Requested on Mar. 13, 2003); United States-Laws, Regulations and Methodology for Calculating Dumping Margins (Zeroing), WT/DS294 (Consultations Requested on Jun. 12, 2003); United States-Measures Relating to Zeroing and Sunset Reviews, WT/DS322 (Consultations Requested on Nov. 24, 2004); United StatesFinal Anti-Dumping Measures on Stainless Steel from Mexico, WT/DS344 (Consultations Requested on May 26, 2006); United States-Continued Existence and Application of Zeroing Methodology, WT/DS350 (Consultations Requested on Oct. 2, 2006); United States-Measures Affecting Trade in Large Civil Aircraft-Second Complaint, WT/DS353 (Consultations Requested on Jun. 27, 2005); United States-Definitive Anti-Dumping and Countervailing Duties on Certain Products from China, WT/DS379 (Consultations Requested on Sep. 19, 2008); United States-Anti-Dumping Administrative Reviews and Other Measures Related to Imports of Certain Orange Juice from Brazil, WT/DS382 (Consultations Requested on Nov. 27, 2008); and United States-Anti-dumping Measures on Certain Shrimp from Viet Nam, WT/DS404 (Consultations Requested on Feb. 01, 2010). 
whereas the other 24 cases that the United States lost but did not settle were coded as " 0 " ("compliant"). This then became the dependent variable for the results presented in Part V.A. ${ }^{104}$

The second task was to determine how to code the length of time it took for compliance to occur. To do so, we collected data on the date that each conference request was filed. ${ }^{105}$ We then also collected data on the date that the United States complied by curing the violation found in the WTO litigation. Measuring the end date was complicated and defining an exact date proved to be difficult. In constructing this variable, we first checked reports filed with the DSB and looked for when the complainant states reported that compliance had occurred. After doing so, we then checked the Federal Register to determine the exact date that the compliance action occurred. When possible, we then used this as the end date for the total compliance time. When we could not determine a date via the Federal Register, we used the date that the complainant state reported to the DSB that the United States was now compliant. ${ }^{106}$ Finally, for cases categorized by the Congressional Research Service as not being fully compliant, we recorded the date that partial compliance occurred; for the three cases where no compliance actions had been taken, we treated these cases as censored observations. ${ }^{107}$ After collecting an end compliance date for each case, we then calculated the number of days that elapsed between when the consultation request was filed and when compliance occurred. This served as the dependent variable for the results reported in Part V.B. Table 2 presents summary information for the dependent variables.

\begin{tabular}{|l|c|c|}
\hline Table 2: Summary of Dependent Variable Collection \\
\hline Category & Total Cases & $\begin{array}{c}\text { Number of Days Until } \\
\text { Compliance (mean) }\end{array}$ \\
\hline Compliant Cases & 24 & 1,022 \\
\hline Non-Compliant Cases & 13 & 2,254 \\
\hline Overall & $\mathbf{3 7}$ & $\mathbf{1 , 4 5 5}$ \\
\hline
\end{tabular}

\section{Independent Variables}

The third step that we took to construct our dataset for this project was to

104. The Congressional Research Service Report was reported before the United States reached an agreement on zeroing cases in February 2012. We attempt to address this issue in our section on robustness. See infra text accompanying notes 163-164.

105. In cases where the complaint was consolidated, the earlier conference request date was used.

106. A list of the sources used to code the compliance data is provided in Appendix C. Appendix C lists WTO sources that were used to code this dependent variable, as well as citations to official U.S. government documents (primarily the Federal Register).

107. See GRIMMETT, supra note 102. The three cases in which the United States is completely non-compliant are: US-Section 211 Appropriations Act, WT/DS176; US-Gambling, WT/DS285; and US-Anti-Dumping and Countervailing Duties (China), WT/DS379. 
collect a range of independent variables that allowed us to operationalize and test our theory of compliance along with competing explanations for if, and when, the United States complies with adverse WTO rulings. We did this by collecting independent variables that capture four features of each dispute.

First, we collected two variables that attempt to capture relevant domestic political features of each dispute. The first variable, Congress Required, is whether congressional action would be required to bring the offending measure into compliance. This is the most critical variable to our paper, and was designed to help us test our theory that the actor expected to supply compliance is a major factor in determining how and when the United States takes steps to comply with WTO decisions. This is a dummy variable coded as "1" ("yes") if Congress would have to take a vote to remove or change legislation to remedy a violation alleged in the initial complaint. The variable was coded as " 0 " ("no") if the United States could become compliant by either allowing a measure to expire, or by the president or an executive agency taking unilateral action. ${ }^{108}$ The second variable in this category is whether there was Divided Government at the time a complaint was filed. This is a dummy variable that was coded as "1" ("yes") if the president's party did not control both houses of Congress, and " 0 " ("no") otherwise. The justification for including this variable in our analysis is that there is evidence that divided government influences the American patterns of adjudication in the WTO. ${ }^{109}$

Second, we collected two variables that are designed to capture the relationship between the United States and the complainant(s). The variable USA Exports attempts to capture the trading relationship between the two countries. ${ }^{110}$ The variable is a natural $\log$ of the total value of the exports from the United States to the complainant's country in the year the conference request was filed. ${ }^{111}$ In cases of multiple complainants, the total value of the exports

108. Several steps were taken to ensure the reliability of the coding of this variable. First, the variable was coded blind based on the content of the initial complaint. Second, the coding of this variable was then discussed with other scholars who have expertise in international trade. The result was that seven cases were coded as requiring congressional action: United States-Tax Treatment for "Foreign Sales Corporations", WT/DS108 (Consultations Requested on Nov. 18, 1997); United States-AntiDumping Act of 1916, WT/DS136 (Consultations Requested on Jun. 4, 1998); United States-Sections 301-310 of the Trade Act 1974, WT/DS152 (Consultations Requested on Nov. 25, 1998); US-Section 110(5) Copyright Act, WT/DS160; United States-Anti-Dumping Act of 1916, WT/DS162 (Consultations Requested on Feb. 10, 1999); US-Section 211 Appropriations Act, WT/DS176; US-Offset Act (Byrd Amendment), WT/DS217; US-Offset Act (Byrd Amendment), WT/DS234; US-Upland Cotton, WT/DS267; and US-Gambling, WT/DS285. In addition, we also attempted to use several alternative codings of this variable in order to avoid the possibility that our substantive results were a consequence of any questionable coding decisions. For a discussion of an alternative approach used to code this variable, see infra notes 158-162 and accompanying text.

109. See DAVIS, supra note 43, at 63. Davis's evidence suggests that divided government influences the decision to bring WTO disputes as a complainant, but her basic argument that constraints on the Executive make negotiations more difficult would suggest it would be more difficult to quickly settle disputes when the United States is the respondent.

110. We also collected data on the flow of imports from the complainant state to the United States. We did not include an "imports" variable in the analysis that we present in this paper because the correlation with exports was 0.95 . Substituting imports for exports does not substantively change our results.

111. This source for this data is the U.S. Dep't of Commerce, Bureau of the Census, Foreign Trade Div., Trade Flow Data for 2011, http://www.census.gov/foreign-trade/about (last visited Apr. 19, 
for the complainant countries was added together. ${ }^{112}$ Additionally, a dummy variable was coded for whether the United States has a Formal Alliance with any of the complainant states. This variable is included because there is evidence that alliances influence the likelihood of trade disputes in the WTO. ${ }^{113}$ A dispute was only coded as "1" ("yes") if one of the complainant countries had a "Type 1" alliance according to the Correlates of War dataset, which signifies that the United States has a formal military alliance with one of the countries that initiated the dispute. ${ }^{114}$ All countries without a Type 1 alliance with the United States were coded as " 0 " ("no").

Third, we collected three variables that were designed to capture the relevant characteristics of the country-or countries in disputes with multiple complainants-that initiated the dispute. The natural log of the country's GDP Per Capita was recorded for the year that the request for consultation was filed. ${ }^{115}$ Additionally, the natural log of the Population was recorded for the year that the request for consultation was filed. ${ }^{116}$ Finally, as a measure of the complainant countries' regime, we use the country's Polity Score. This is a measure of whether a country is autocratic or democratic on a scale of -10 to 10 . This variable is based on the "polity2" variable from the Polity IV project. 117

Fourth, we collected two variables that capture the characteristics of the individual dispute. ${ }^{118}$ For the first, we coded whether each case was a Trade

2014).

112. For a discussion of an alternative approach used for cases with multiple complainants, see infra text accompanying notes 166-168.

113. See DAVIS, supra note 43 , at $92-100$. It is worth noting that there are many other recent studies on WTO disputes that do not include a variable for alliances between dyads. Id. at 93 . We believe, however, that after Davis' research it is appropriate to include this measure.

114. This data is from the Correlates of War Formal Alliance dataset. Alliances (v. 4.01), CORRELATES OF WAR, http://www.correlatesofwar.org/COW $2 \% 20$ Data/Alliances/alliance.htm (last visited Mar. 12, 2014). See Douglas M. Gibler \& Merideth R. Sarkees, Measuring Alliance: The Correlates of War Formal Interstate Alliance Dataset, 1816-2000, 41 J. PEACE RESOL. 211 (2004); see also DOUGLAS M. GIBLER, INTERNATIONAL MILITARY ALLIANCES, 1648-2008 (2009). It is worth noting that we have elected to use the "COW" Alliance data set as opposed to the "ATOP" dataset. Although the ATOP dataset was used by Davis, the ATOP data is only available through 2004. See DAVIS, supra note 43 , at 94 . In contrast, the COW data is extended to 2008 , and thus covers a greater portion of our sample. See Gibler \& Sarkees, supra.

115. This data is from the World Bank Development Indicators. World Development Indicators, WORLD BANK, http://data.worldbank.org/data-catalog/world-development-indicators (last visited Mar. 12, 2013). Since Taiwan is not included in the World Bank data, Taiwan's GDP Per Capita was taken from the CIA World Factbook. The World Factbook, CENT. INTELLIGENCE AGENCY, https://www.cia.gov/library/publications/the-world-factbook (last visited Mar. 12, 2014).

116. See World Development Indicators, supra note 115.

117. See Monty G. Marshall, Keith Jaggers \& Ted Robert Gurr, Polity IV Project: Political Regime Characteristic and Transitions, 1800-2012, CENTER. FOR SYSTEMIC PEACE, $\mathrm{http}: / /$ www.systemicpeace.org/inscr/inscr.htm (last updated June 10, 2013). Our coding required making three adjustments due to limitations of the polity data. First, the European Union was given a value of "10" in all years. Second, Antigua and Barbuda are not included in the Polity IV dataset, but were coded as 5 based on a value of 4 in the Freedom House Political Freedom Index (which translated to a polity score of 5 for other countries with the same Freedom House score). Third, disputes with multiple complainants had their polity score averaged.

118. Unfortunately, it is not possible to directly control for the "value" of the dispute. The value of dispute is not determined during the dispute resolution process and is only set if retaliation is authorized (which happens rarely). Additionally, the parties tend to have vastly different views of the amount of trade losses - i.e. in the U.S.-Antigua gambling dispute, the United States argued that the annual val- 
Remedy Case. ${ }^{119}$ This is because there is reason to believe that the United States has a particularly harsh reaction to trade remedy disputes. ${ }^{120}$ Disputes were coded as Trade Remedy cases if they were classified by the WTO for being about anti-dumping, safeguards, or countervailing measures. For the second, we coded the Contributions made in the United States by interest groups and lobbyists representing the sector at issue in each dispute. This variable is important because it has been understood that interest groups have a significant influence on U.S. trade policy. ${ }^{121}$ As a result, we coded each dispute as relating to one of thirteen sectors based on a categorization scheme developed by the Center for Responsive Politics. ${ }^{122}$ The total political contributions made by each sector to candidates and committees in the election cycle prior to when the request for consultation was filed was then taken. ${ }^{123}$ Although scholars have used both political contributions ${ }^{124}$ and sector employment ${ }^{125}$ as measures of the political influence of industries when studying compliance with WTO decisions, we believe that using the political contributions variable is the most direct way to capture which industries will have political clout that might influence the U.S. government's compliance decisions. ${ }^{126}$ Table 3 provides a summary of the independent variables. ${ }^{127}$

ue of the lost trade was $\$ 3.3$ million, Antigua put it at $\$ 3.443$ billion, and the panel finally awarded $\$ 21$ million. See Report of the Arbitrator, United States-Measures Affecting the Cross-Border Supply of Gambling and Betting Services, WT/DS285/ARB (Dec. 21, 2007).

119. Trade Remedies are policy responses that are taken in response to adverse consequences of trade policies. For general information, see KENNEDY, supra note 74, at 547-48.

120. See William F. Davey, The WTO Dispute Settlement System: The First Ten Years, 8 J. INT'L ECON. L. 17, 24-25 (2005) ("[I]n terms of controversy, the WTO dispute settlement system has been controversial in recent times mainly because of the very critical reaction in Washington to US losses in ... trade remedy cases.").

121. See, e.g., YoUNG, supra note 54, at 161-62.

122. Information on this data is available at About the Data in These Industry Profiles, CENTER. RESPONSIVE POL., http://www.opensecrets.org/industries/methodology.php (last visited Mar. 12, 2014).

123. There are two types of cases for which it is difficult to classify which sector of the economy is affected. First, for zeroing cases we used "steel" as the affected industry because the underlying products were primarily forms of steel (e.g., steel bearings). Second, to provide the most difficult test for our theory, for cases that did not directly implicate a specific industry (e.g., United States-Tax Treatment for "Foreign Sales Corporations", WT/DS108 (Consultations Requested on Nov. 18, 1997)), we classified these disputes as being part of the sector with the highest donations in the previous election cycle.

124. See DAVIS, supra note 43 , at $126-27$.

125. See Hofmann \& Kim, supra note 50.

126. It should be noted that the natural $\log$ of this variable was used in our analysis.

127. Summary statistics for the independent variables are in Appendix A. 
Table 3: Summary of Variables Included in the Dataset

\begin{tabular}{|c|c|c|c|}
\hline Category & Variable & Values & Source \\
\hline \multicolumn{4}{|c|}{ OUTCOMES } \\
\hline & Compliance & $0=$ no $; 1=$ yes & CRS Report \\
\hline & Compliance Time & & Various Sources \\
\hline \multicolumn{4}{|c|}{ DOMESTIC FACTORS } \\
\hline & Congress Required & $0=$ no $; 1=$ yes & Various Sources \\
\hline & $\begin{array}{l}\text { Divided } \\
\text { Government }\end{array}$ & $0=$ no $; 1=$ yes & $\begin{array}{l}\text { Database of } \\
\text { Political } \\
\text { Institutions }\end{array}$ \\
\hline \multicolumn{4}{|c|}{ RELATIONSHIP FACTORS } \\
\hline & U.S. Exports & $\begin{array}{l}4.85(\mathrm{~min}) \text { to } \\
13.30(\max )\end{array}$ & $\begin{array}{l}\text { Dep't of } \\
\text { Commerce }\end{array}$ \\
\hline & Formal Alliance & $0=$ no $; 1=$ yes & $\begin{array}{l}\text { COW Formal Alli- } \\
\text { ance Dataset }\end{array}$ \\
\hline \multicolumn{4}{|c|}{ COMPLAINANT CHARACTERISTICS } \\
\hline & GDP Per Capita & $\begin{array}{l}6.01(\min ) \text { to } \\
12.02(\max )\end{array}$ & $\begin{array}{l}\text { World Bank De- } \\
\text { velopment Indica- } \\
\text { tors }\end{array}$ \\
\hline & Population & $\begin{array}{l}11.31(\min ) \text { to } \\
21.57(\max )\end{array}$ & $\begin{array}{l}\text { World Bank De- } \\
\text { velopment Indica- } \\
\text { tors }\end{array}$ \\
\hline & Polity Score & $\begin{array}{l}-10(\min ) \text { to } \\
10(\max )\end{array}$ & $\begin{array}{l}\text { Polity IV } \\
\text { Project }\end{array}$ \\
\hline \multicolumn{4}{|c|}{ DISPUTE FACTORS } \\
\hline & $\begin{array}{l}\text { Trade Remedy } \\
\text { Case }\end{array}$ & $0=$ no $; 1=$ yes & Various Sources \\
\hline & $\begin{array}{l}\text { Political } \\
\text { Contributions }\end{array}$ & $\begin{array}{l}17.62(\min ) \text { to } \\
19.86(\max )\end{array}$ & $\begin{array}{l}\text { Center for } \\
\text { Responsive } \\
\text { Politics }\end{array}$ \\
\hline
\end{tabular}




\section{RESULTS}

After building this original dataset, we performed a number of statistical tests to determine whether the domestic sources of policy actions needed to bring the United States into compliance with WTO decisions directly influenced whether and when the United States complied. In this Part, we present the results of those tests. First, we present models that estimate the influence the Congress Required variable and other variables have on whether the United States actually complied with the WTO's ruling. Second, we present models that estimate the influence of the Congress Required variable on the amount of total time that elapsed from when a conference request was filed until the United States came into compliance. Third, we discuss a series of robustness checks that we performed to try and ensure that our results were not merely a result of coding decisions or model dependency. All of our results provided strong support to our theory that the actor required to comply is a significant determinate of if, and when, the United States complies with WTO decisions.

\section{A. Compliance}

The first test of our theory that we performed is estimating the impact of whether Congress was required to act on whether the United States fully complied with the WTO's rulings. For this test, the number of observations was the 37 disputes that the United States did not settle or where the United States did not prevail on the core issue in the dispute. Of these 37 cases, there were 13 disputes where the United States was not being fully compliant as of January 25,2012 . We then estimated a series of logit models that estimated the impact that a range of variables had on whether a case would be one of the 13 noncompliant cases. ${ }^{128}$ Logit analysis is a standard social science method of analyzing how independent variables influence a binary outcome ${ }^{129}$; in our case, compliance with the WTO's ruling. Figure 1 presents the results of these tests. ${ }^{\text {I30 }}$

128. It is worth noting that the decision to use logit models, as opposed to probit models, did not substantively affect our results.

129. See ANDREW Gelman \& JENNIFER Hill, DATA ANALYSIS USING REgRESSIONS AND MULTILEVEL/HIERARCHICAL MODELS 79 (2007).

130. All statistical analysis for this study was conducted using "Zelig" for R. See Kosuke Imai, Gary King \& Olivia Lau, Toward a Common Framework for Statistical Analysis and Development, $17 \mathrm{~J}$. COMPUTATIONAL \& GRAPHICAL STAT. 892 (2008); see also Zelig: Everyone's Statistical Software, HARV. U. INST. FOR QUANTITATIVE SOC. SCI., http://gking.harvard.edu/zelig (last visited Mar. 12, 2014) (describing the purpose and functions of "Zelig"). 
Figure 1: Logit Models Estimating Likelihood of Non-Compliance

Model 1
Compliance
$(\mathrm{n}=37)$

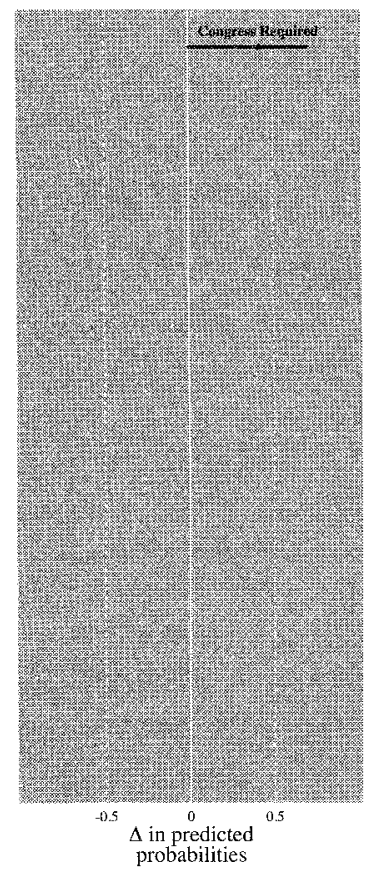

\author{
Model 2 \\ Compliance \\ $(\mathrm{n}=37)$
}

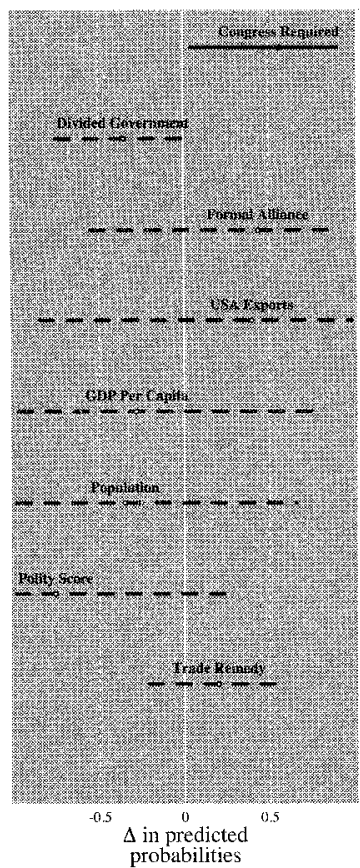

Model 3

Compliance

$(n=37)$

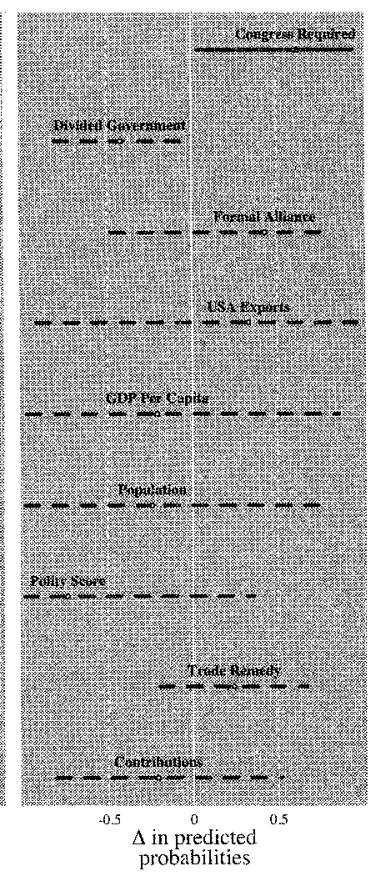

Figure 1 presents our statistical results graphically. ${ }^{131}$ Each box is a logit model estimating compliance with WTO decisions as the dependent variable. The Figure presents the simulated first differences as each variable moves from its minimum to maximum value. ${ }^{132}$ In each of the three boxes, every line represents the point estimate and the $95 \%$ confidence interval for an individual variable included within the model. ${ }^{133}$ Point estimates to the right of zero mean that the variable is associated with a high probability of non-compliance. Statistically significant variables are presented as solid lines, and all others are dotted lines.

131. For a defense of the merits of presenting regression results graphically, see Jonathan $P$ Kastellec \& Eduardo L. Leoni, Using Graphs Instead of Tables in Political Science, 5 PERSP. ON POL. 755 (2007). For traditional regression tables, see Appendix B.

132. For a discussion of the merits of using simulated first differences, see Gary King, Michael Tomz \& Jason Wittenberg, Making the Most of Statistical Analyses: Improving Interpretation and Presentation, 44 AM. J. POL. SCI. 341 (2000). See also GARY KING, UNIFYING POLITICAL Methodology: The Likelihood Theory of StATISTICAL INFERENCE 107-08 (1998) (providing a technical discussion of simulating first differences for producing quantities of interest from regressions).

133. We include the line representing the confidence interval because all statistical estimates have a certain degree of uncertainty. The intuition for including a line with the confidence interval is that we can say with $95 \%$ confidence that the true estimate of the effect of a given variable falls within the confidence interval that we present. 
As Figure 1 clearly shows, in each of the three models estimated, disputes where Congress was required to act are associated with roughly a $50 \%$ higher probability that the United States will be non-compliant with a WTO decision. This ranges from a $42 \%$ higher probability in Model 1 to a $63 \%$ higher probability in Model 3. This result is consistent with the parsimonious model presented in Model 1, ${ }^{134}$ when controlling for a range of independent variables that account for alternative explanations in Model $2,{ }^{135}$ and even when including data on the political contributions associated with the relevant sector of the economy at issue in the dispute in Model $3 .^{136}$ In fact, not only is the Congress Required variable significant in each model presented, it is the only variable that achieves statistical significance at the five percent level. ${ }^{137}$ These results thus lend strong support to our theory that the institutional source of domestic policy action is a significant component of the state's decision of whether to comply with WTO decisions.

Figure 1 also provides evidence on what other factors influence, or do not influence, compliance decisions. These results should not only be of interest to scholars of international trade, but also scholars of international relations more broadly. ${ }^{138}$ The results in neither Model 2 nor Model 3 provide any evidence that characteristics about the complaining state or states influence the U.S. government's likelihood of complying with WTO decisions. Interestingly, the level of U.S. exports to the complaining state, which is a measure of the potential retaliatory capability of the complaining state, does not have any stastically significant effects. ${ }^{139}$ This is contrary to realists ${ }^{140}$ and institutionalists ${ }^{141}$ approaches to international relations expectations that

134. P-value $=0.04$.

135. P-value $=0.04$.

136. P-value $=0.04$.

137. The Divided Government variable narrowly misses statistical significance at the 0.05 level in Models 2 and 3. In Model 2, the p-value for Divided Government is 0.07. In Model 3, the p-value for Divided Government is 0.06 .

138. For an easy to follow review of the major theories of international relations, see Stephen M. Walt, International Relations: One World, Many Theories, 110 FOREIGN POL'Y 29 (1998).

139. In Model 2, the p-value for USA Exports is 0.32. In Model 3, the p-value for USA Exports is 0.42 .

140. Realist approaches to international law and international relations focus primarily on the perceived national interests of the state and the distribution of power within the international system. Realist approaches to international law question whether treaty rules or customary law are a real constraint on state action or simply a reflection of powerful state preferences. Most realist accounts adopt a model of state decision-making that is unitary and focused on external threats. Because of the overwhelming effects of the international system's constant security competition on states, governments must take the actions that maintain the state's power. Realists downplay the importance of domestic politics, describing state decision-making as essentially identical even though domestic political systems may vary significantly. The importance of systemic threats leads realists to expect political bodies within a state to respond similarly (if not identically) to external pressure, even on economic issues. For examples of realist thinking on international law and international relations, see GOLDSMITH \& POSNER, supra note 53; and John Mearsheimer, The False Promise of International Institutions, 19 INT'L SECURITY 5 (1994).

141. Institutionalist approaches to compliance are also focused on the competitive pressures of the international system on state decision-making, but anticipate that the structure of the regime itself may promote compliance. Institutions can build webs of cooperation and establish linkages across issue areas. Failure to cooperate in one issue area reverberates throughout the international system and raises the costs of non-compliance. For instance, establishing a legal regime engages the state's reputation for 
concerns for retaliation or reciprocity are driving governments' compliance decisions. In addition, the existence of other formal alliances with complaining states also does not have a statisticaly significant influence on compliance. ${ }^{142}$ While this finding does not disprove the institutionalist's expectation that having more formal treaty alliances will lead to greater linkages between regimes and thus greater compliance in all regimes, ${ }^{143}$ the evidence is not supportive of the idea that a web of treaty relationships between country dyads will improve compliance. In addition, the results of Model 2 and Model 3 do not support the conjecture by liberal theory that democracies will be more likely to comply with international obligations when dealing with other democracies. ${ }^{144}$ A higher polity score, indicating more democratic institutions, did not have any statistically significant effect on United States compliance levels, indicating that the United States is no more likely to comply with international law obligations to other democracies than to non-democracies. ${ }^{145}$

More broadly, none of the independent variables accounting for external pressures on the state to comply were statistically significant. This suggests as a general matter that domestic pressure, rather than international pressure, is responsible for understanding the variance in U.S. compliance decisions. This does not necessarily mean that external pressure is not a significant cause of compliance. Rather, it is possible that the level of external pressure to comply may be constant for all cases, and so external pressure is not a good predictor of when the United States chooses to comply (or not) for any particular case. The level of external pressure may help establish a baseline level of compliance for

abiding by its promises and creates incentives for states to comply with its cooperative obligations. Institutional theory views states as being in a security competition, but does not view this competition as an overwhelming concern as realists do. Relative power considerations are not so dominant that govemments cannot decide to cooperate with one another on a variety of economic or military issues. As such, institutionalists understand states as having more space for policy choice, and correspondingly, a greater possible role for domestic politics. Nonetheless, institutionalists would not necessarily expect that different parts of the government would respond differently to international pressure and do not have any specific predictions for how the supply of a policy would influence its content. For examples of institutionalist thinking on international law and international relations, see ROBERT O. KEOHANE, AFTER HEGEMONY: COOPERATION AND DISCORD IN THE WORLD POLITICAL ECONOMY (1984); GUZMAN, supra note 48 .

142. In Model 2, the p-value for Formal Alliance is 0.18 . In Model 3, the p-value for Formal Alliance is 0.18 .

143. See, e.g., KEOHANE, supra note 141 .

144. Liberal theory provides a more differentiated view of state decision-making. Liberal theory argues that states act in systemically different ways depending on their form of government and the policy preferences of sub-state actors. In one notable variant of liberal theory, Anne-Marie Slaughter argues that democratic states have internalized the rule of law far more than non-democratic states and thus comply with international law far more. See, e.g., Anne-Marie Slaughter, International Law in a World of Liberal States, 6 EUR. J. INT'L L. 503 (1995). Slaughter also argues that democratic states treat each other differently than non-democratic states. Because other democracies share their rule of law values (in addition to the web of economic and social relationships between democracies), democratic states will comply with their legal obligations to one another more than their obligations with regards to nondemocracies. While our study cannot test whether the United States complies more with international law and international judicial decisions more often than non-democracies, it can examine whether the United States acts differently based on the form of government in a complaining state. Liberal theory would expect that the rates of compliance would be higher with regards to democracies than nondemocracies.

145. In Model 2, the p-value for Polity Score is 0.13. In Model 3, the p-value for Polity Score is 0.13 . 
all cases but does not predict movement around the baseline. However, the fact that dyad specific factors are not important is still notable. Basic realist propositions, such as the idea that the United States is more likely to comply when sued by a more economically powerful state, turn out to not be supported. Neither are propositions that "interdependence" between country dyads (through shared democratic governance structure or formal alliances) should lead to greater compliance with treaty obligations borne out.

Finally, the other case specific variables were also not relevant to the compliance decision. The level of political contributions in Model 3 did not have a statistically signficant influence on compliance. ${ }^{146}$ This is notable because it indicates that a simple interest group lobbying model is not a very good predictor of compliance on trade issues. More importantly for this study, controlling for political contributions means that differences between the actions of Congress as compared to the actions of the executive branch are not driven by interest group action. The differences between U.S. compliance decision when congressional action is needed or not persist even when we account for political contributions. This result means that it more likely that the nature of the two institutions, not interest group politics, makes the Congress Required variable important. The study also accounts for cases that challenge American domestic trade remedy actions. Trade remedy actions involve domestic level decisions to apply safeguards, anti-dumping measures, and countervailing duties, and these decisions are frequently challenged at the WTO. To make sure that these cases were not driving our results, we included a dummy variable to account for any trade remedy specific variation. Some trade scholars may be surprised that this variable is not statistically significant, indicating that the United States is no more likely to comply in a trade remedy cases than in any other issue area. ${ }^{147}$

\section{B. Total Compliance Time}

The second test of our theory was estimating the impact of whether congressional action was required to bring a measure into compliance on the total amount of time that compliance took. The total amount of time that compliance takes is a measure of the quality of compliance. Because the WTO litigation process can be manipulated by dragging out the panel and appeals process through requests for compliance panels and other delaying tactics, discussion of compliance are not exclusively focused on whether a nation ultimately complied but also on how long compliance takes. ${ }^{148}$ This test attempts to measure the quality of compliance by accounting for the compliance timeline.

For these tests, once again, the number of observations was the thirty-

146. The p-value is 0.50 . edy is 0.19 .

147. In Model 2, the p-value for Trade Remedy is 0.24 . In Model 3, the p-value for Trade Rem-

148. See, e.g., Rachel Brewster, The Remedy Gap: Institutional Design, Retaliation, and Trade Law Enforcement, 80 GEO. WASH. L. REV. 102 (2012); William J. Davey, Compliance Problems in WTO Dispute Settlement, 42 CORNELL INT'L L.J. 119 (2009). 
seven disputes where the United States did not settle or prevail on the core issue in the case. ${ }^{149}$ For each of these cases, the dependent variable was calculated as the number of days from when the conference request was filed until when the United States took an action to come into compliance. ${ }^{150}$ We did so using a series of Cox Proportionate Hazard ("Cox PH") Models. ${ }^{151}$ Cox PH models estimate the influence that a given independent variable has on "survival." That is, how long until a time period will end. The reason that we selected the Cox PH model, instead of a different durational model, is that it has the advantage of not requiring assumptions about the distribution of time until an event occurs. ${ }^{152}$ Figure 2 presents the results of these tests.

Using a similar method to the one we used to present results in the last Section, ${ }^{153}$ Figure 2 presents graphical representations of three Cox PH regression models. These three models include the same independent variables as Figure 1. The difference, however, is that Figure 1 presented the results of logit models that can be interpreted as the change in probability that an event will occur-in our case, non-compliance with a WTO decision. In contrast, the results presented in Figure 2 are hazard ratios. Hazard ratios with a value of less than 1.0 mean that an event will take longer to occur, whereas hazard ratios with a value of greater than 1.0 is likely to occur more quickly.

In all three of the models included in Figure 2, the Congress Required variable is below 1.0 and is statistically significant. The hazard ratio in these models for the Congress Required variable ranges from 0.23 in Model 1 to 0.06 in Model 3. In all three cases, this result is statistically significant at the 0.01 level. ${ }^{154}$ In other words, these models suggest that we can say with $99 \%$ confidence that the disputes that require congressional action to be resolved take longer for compliance to occur than other disputes. This result is robust whether the parsimonious model is used or all of our covariates are included. These results support our theory by presenting strong evidence, even controlling for competing theories, that the identity of the branch whose action is required to provide compliance has a significant impact on how long it takes the United States to comply with adverse WTO rulings.

Figure 2 also presents interesting results with regards to competing hypotheses concerning compliance. Again, the retaliatory capacity of the complaining state (or states) does not speed up compliance. ${ }^{155}$ The polity score of

149. See supra Table 1.

150. For the thirteen cases in which the United States was non-compliant, we used the date when the United States came into at least partial compliance. The three cases in which no steps have been taken are treated as censored observations as of August 31, 2012.

151. For a discussion on the use of durational models generally, see JANET M. BoXSTEFFENSMEIER \& B. S. JONES, EVENT HisTORY MODELING: A GUIDE FOR SOCIAL SCIENTISTS (2004); and Jim E. Alt, Gary King \& Curtis S. Signorino, Aggregation Among Binary, Count, and Duration Models: Estimating the Same Quantities From Different Levels of Data, 9 POL. ANAL. 21 (2001).

152. Janet M. Box-Steffensmeier \& Christopher J. W. Zorn, Duration Models and Proportionate Hazards in Political Science, 45 AM. J. POL. SCI. 972, 974 (2001).

153. See supra text accompanying note 132 .

154. In Model 1, the p-value for Congress Required is 0.004. In Model 2, the p-value for Congress Required is less than 0.001. In Model 3, the p-value for Congress Required is 0.001 .

155. In Model 2, the p-value for USA Exports is 0.27. In Model 3, the p-value for USA Exports 
the complaining state is not significant indicating that the United States is not more likely to comply with adverse WTO judgments faster if the complaining state is another democracy. ${ }^{156}$ More difficult to explain is the formal alliance variable. This independent variable is statistically significant but it works in the opposite manner than institutional theory would predict. ${ }^{157}$ The United States is likely to take longer to comply with WTO decisions when it has a formal alliance with the complaining state than when the complaining state is not a security ally. The direction of the variable indicates that having greater interdependence in formal treaty regimes does not lead to a higher quality of compliance in terms of timing.

\section{Robustness Checks}

To help ensure that our results are not the result of either coding decisions or model dependence, we performed a number of robustness checks. Each of these checks present further evidence to support our theory that a driving factor determining the United States' compliance with WTO decisions is which branch of government is required to take action.

First, one concern is that our coding decisions of the Congress Required variable may not have included all of the cases where congressional action was required for the United States to remedy the violation alleged in the initial complaint. Given that our initial coding of the variable was intentionally conservative to create a difficult test for our theory, we coded four alternative versions of the Congress Required variable to ensure that our results were not based solely on our cautious coding decisions. For these alternative variables, we added additional cases to our initial list of those requiring congressional action. Specifically, we changed the coding of: (1) United States-HelmsBurton; ${ }^{158}$ (2) United States-Softwood Lumber III; ${ }^{159}$ (3) Zeroing cases; ${ }^{160}$ and (4) all three of the previous cases simultaneously. ${ }^{161}$ We then re-estimated the models presented in Figures 1 and 2 using each of the four alternate versions of the Congress Required variable. For all of the models and alternative

is 0.27 .

156. In Model 2, the p-value for Polity Score is 0.41. In Model 3, the p-value for Polity Score is 0.47 .

157. In Model 2, the p-value for Formal Alliance is 0.02 . In Model 3, the p-value for Formal Alliance is 0.03 .

158. This is dispute DS38. United States-The Cuban Liberty and Democratic Solidarity Act, WT/DS38 (Consultations Requested on May 3, 1996).

159. This is dispute DS236. United States-Preliminary Determinations with Respect to Certain Softwood Lumber from Canada, WT/DS236 (Consultations Requested on Aug. 21, 2001).

160. These are disputes DS294, DS322, DS350, and DS402. United States-Laws, Regulations and Methodology for Calculating Dumping Margins (Zeroing), WT/DS294 (Consultations Requested on Jun. 12, 2003); United States-Measures Relating to Zeroing and Sunset Reviews, WT/DS322 (Consultations Requested on Nov. 24, 2004); United States-Continued Existence and Application of Zeroing Methodology, WT/DS350 (Consultations Requested on Oct. 2, 2006); and United States-Use of Zeroing in Anti-Dumping Measures Involving Products from Korea, WT/DS402 (Consultations Requested on Nov. 24, 2009).

161. These are disputes DS38, DS236, DS294, DS322, DS350, and DS402. US-Helms Burton, WT/DS38; US-Softwood Lumber III, WT/DS236; US-Zeroing (EC), WT/DS294; US-Zeroing (Japan), WT/DS322; US-Continued Zeroing, WT/DS350; and US-Zeroing (Korea), WT/DS402. 
variables, the results were substantially the same as those presented in the paper. $^{162}$

Second, another concern may be that our results for estimating whether the United States would comply with an adverse WTO decision presented in Figure 1 were driven by the timing of the Congressional Research Service (CRS) report that we used to code the dependent variable. ${ }^{163}$ The concern is that shortly after the CRS report was released, the United States finally reached a deal to resolve a number of zeroing cases. As a result, we created an alternate dependent variable that changed the coding for the three zeroing cases listed in the CRS report as non-compliant to compliant. ${ }^{164}$ After doing so, we reestimated the models presented in Figure 1. The Congress Required variable remained statistically significant at the 0.05 level or higher in all three models.

Third, it is possible that the models that we used to estimate the total compliance time were biased because the models presented in Figure 2 did not include cases that had been settled. To address this possibility, we collected data on the amount of time that elapsed during the litigation and compliance process for cases that ultimately settled. The impact for Figure 2 was that there were eleven additional cases that we have information on when the settlement took place (for the other seven settled cases, it does not appear that the result of the negotiations was ever reported to the DSB, and thus we do not know even the rough date of when the United States took a compliance action). ${ }^{165}$ After including these cases, we re-estimated the models presented in Figure 2 with 48 instead of 37 observations. In all three models, the Congress Required variable remains statistically significant at the 0.01 level or higher.

Fourth, it would be reasonable to be concerned that our results were at least partially driven by our decision on how to code control variables for cases brought by multiple complainants. ${ }^{166}$ For cases with multiple complainants, we

162. The variable for Congress Required is statistically significant at least at the 0.05 level for 21 of 24 models estimated for this robustness check. The exception is the models in Figure 1 when the Congress Required variable was altered to include only the softwood lumber case (DS236). Of these, Model 1 and Model 2 were significant at the 0.1 level, but Model 3 in Figure 1 has a p-value of 0.12 .

163. See supra notes $102-104$ and accompanying text.

164. These are disputes DS294, DS322, and DS350. US-Zeroing (EC), WT/DS294; USZeroing (Japan), WT/DS322; and US-Continued Zeroing, WT/DS350.

165. The eleven additional cases are: DS6, DS32, DS38, DS39, DS49, DS85, DS88, DS89, DS250, DS281, and DS282. United States-Imposition of Import Duties on Automobiles from Japan under Sections 301 and 304 of the Trade act of 1974, WT/DS6 (Consultations Requested on May 17, 1995); United States-Measures Affecting Imports of Women's and Girls' Wool Coats, WT/DS32 (Consultations Requested on Mar. 14, 1996); US-Helms Burton. WT/DS38; United States-Tariff Increases on Products from the European Communities, WT/DS39 (Consultations Requested on Apr. 18, 1996); United States-Anti-Dumping Investigation Regarding Imports of Fresh or Chilled tomatoes from Mexico, WT/DS49 (Consultations Requested on July 1, 1996); United States-Measures Affecting Textiles and Apparel Products, WT/DS85 (Consultations Requested on May 22, 1997); United States-Measure Affecting Government Procurement, WT/DS88 (Consultations Requested on Jun. 20, 1997); United States-Anti-Dumping Duties on Imports of Colour Television Receivers from Korea, WT/DS89 (Consultations Requested on Jul. 10, 1997); United States - Equalizing Excise Tax Imposed by Florida on Processed Orange and Grapefruit Products, WT/DS250 (Consultations Requested on Mar. 20, 2002); United States-Anti-Dumping Measures on Cement from Mexico, WT/DS281 (Consultations Requested on Jan. 31, 2003); United States-Anti-Dumping Measures on Oil Country Tubular Goods (OCTG) from Mexico, WT/DS282 (Consultations Requested on Feb. 18, 2003).

166. This includes both consolidated cases and cases where two countries were complainants on 
elected to code the Exports, GDP Per Capita, and Population as the sum of the totals for all of the complainants, and the Polity Score as the average for all of the complainants. In their paper on compliance with WTO decisions, however, Hofmann and Kim took an alternate approach and elected to code control variables based on the values for the complainant with the largest GDP. ${ }^{167}$ Although we are generally concerned that this approach fails to account for the possibility that the stakes may be meaningfully higher when there are multiple complainants than if the complainant with the largest GDP had brought the complaint alone, we recoded our variables for USA Exports, GDP Per Capita, Population, and Polity Score using Hofmann and Kim's approach. After recoding these variables for cases with multiple complainants, we re-estimated the models presented in Figures 1 and 2. After doing so, our results remained substantively the same. ${ }^{168}$

Fifth, a final concern that we attempted to address is the fact that the measure of compliance time presented in Figure 2 could be biased because measuring from when a conference request was filed until compliance means our variable includes both the "litigation time" and the "compliance time." It could be the case that in disputes where Congress is required to act it takes longer to litigate, but that after the litigation has completed, the United States complies just as promptly as in other cases. To ensure that this possibility was not driving our results, we attempted to directly measure "compliance time": for each case we collected the date that the final panel or appellate body report for each case was adopted. We then calculated the number of days that elapsed from this point until the date when compliance occurred. After doing so, we reestimated the models presented in Figure 2 with this new dependent variable. The significance and substantive effect of the Congress Required variable was comparable to the results presented in Figure 2, and thus did not substantively change the results.

\section{CONCLUSION}

The question of why and when states comply with international law is one of the foundational inquiries in international legal studies. This work attempts to examine compliance actions empirically by studying the compliance behavior of the United States in response to adverse WTO dispute resolution decisions. Of course, focusing on the U.S. government alone has limitations in terms of how well the findings here can generalize to either other substantive areas of international law and other states. Our results are unique to this topic, and as a consequence we would advocate more research on the supply side of compliance. That said, we still believe it is worth considering the implications that this study's results have for understanding states' compliance with international law more broadly.

the same request for consultation.

167. See Hofmann \& Kim, supra note 50, at 118.

168. The models in Figure 1 had a p-value of 0.06 , whereas the models in Figure 2 were significant at the 0.01 level. 
First, opening the "black box" of the state is critical to explaining patterns of compliance. Different domestic actors can be the source of policy compliance on various issues. This study demonstrates that when the executive branch has the power to comply with adverse WTO decisions, then the likelihood of compliance is significantly higher and compliance comes significantly faster than if congressional action is needed. This result is important because it demonstrates that states are not unitary actors when it comes to compliance decisions. The structure of the domestic political system influences the rate of compliance across policy issues.

Our empirical analysis finds that the question of who supplies compliance overwhelms the influence of all international factors in predicting compliance, including the economic size of the complaining state, and all other domestic factors, including political contributions. Which actor within the state has the capacity to cure the violation is not only significant in determining the state's compliance, it is also the most important characteristic in explaining compliance. This suggests that it is not useful to talk about a state's level of compliance when analyzing patterns of compliance. Rather, compliance behavior must be disaggregated based on the source of compliance in order to be coherently understood. If members of Congress are fundamentally less receptive to appeals that abide by international obligations than members of the executive branch (either because of their constituencies, their lack of participation in the day-to-day practice of foreign affairs, or super-majority voting rules) then our focus should shift to more domestic level variables to understand the effects of international law.

This study also suggests that international relations theories that have expectations for "state" action may be overly broad. Different actors within a state may operate based on different logics. Therefore, the effort to treat the state as unitary obscures important causal factors. Our study is generally supportive of the idea that executive branch actors may experience more of a "compliance pull" from international law than members of Congress. This could be based on the executive branch's day-to-day operation of foreign affairs, concerns about reciprocity with foreign counterparts, or perception of the legitimacy of the dispute resolution process. Members of Congress may have lower concerns about reciprocity (particularly on a daily basis), have less exposure to the dispute settlement processes, and thus, have lower levels of confidence in the legitimacy of the process. Thus the supply-side approach opens up a new area of compliance research that has broad implications for theories of compliance, in addition to more narrow proposals for designing dispute settlement regimes.

In broad brushstrokes, this study indicates that institutionalist logic may have more force when dealing with executive branch officials. Concerns about reputation or a desire to be perceived as a "law-abiding" state may have greater influence on government officials who deal with the international system directly. ${ }^{169}$ In addition, the managerialist approaches that emphasize the im-

169. For a discussion of the role of reputation in furthering compliance with intemational law, 
portance of "jaw-boning" or "shaming" may also find a more fertile ground when dealing with executive branch officials. ${ }^{170}$ By contrast, members of Congress may not be influenced by concerns about the perceptions of foreign policymakers or international officials because they interact with these audiences less often. Jaw-boning may be less effective with members of Congress because they are not at the bargaining table. Furthermore, the same activities that might be embarrassing to an executive branch official, such as openly refusing to abide by an international court decision, may be the source of pride or greater domestic support to a member of Congress.

When dealing with members of Congress, other models may better describe compliance behavior. Members of Congress appear less responsive to the current levels of prospective remedies available at the WTO than the executive branch. Nonetheless, legislators may nonetheless be responsive to the material consequences of non-compliance that would affect their constituencies. Thus, the levels of cooperation that can be sustained when legislative action is necessary may depend on the level of retaliation that can be authorized for noncompliance. ${ }^{171}$ In dispute settlement design terms, this means that permitting higher retaliatory remedies, including retrospective damages or progressively higher damages, may be helpful to create the necessary domestic conditions for compliance to occur.

Many WTO disputes end in negotiated settlements. The litigating parties agree to an outcome that falls short of full compliance with the WTO adjudicatory decision. ${ }^{172}$ Interestingly, in bargaining for a settlement, the well-known intransigence of the U.S. Congress in complying with WTO decisions may be a bargaining asset. Two-level bargaining suggests that having a domestic barrier to compromise makes a state's bargaining position more credible. ${ }^{173}$ Where legislative action is needed to cure the violation, the Executive can credibly argue that United States is unlikely to comply fully or quickly because of the difficulty of securing the necessary congressional action and, thus, the complaining state should accept a settlement that is less than what the WTO law demands.

For instance, in the ongoing dispute between the United States and Brazil over American subsidies to cotton farmers, the American Executive has been able to use legislative intransigence as part of its bargaining strategy. To cure the breach of WTO rules, the United States needs to alter the level and type of subsidies that it offers to cotton farmers. Agriculture subsidies are generally included as part of the U.S. "Farm Bill" that Congress considers every five

see GuZMAN, supra note 48, 7-11; KEOHANE, supra note 141; and Abbott \& Snidal, supra note 48, at 127-131.

170. Abram Chayes \& Antonia Handler Chayes, On Compliance, 47 INT'L ORG. 175 (1993).

171. See generally GoLDSMITH \& POSNER, supra note 53, at 153-66; Downs, Rocke \& Barsoom, supra note 2 , at 381 .

172. See Rachel Brewster, Pricing Compliance: When Formal Remedies Displace Reputational Sanctions, 54 HARV. INT'L L.J. 259, 285 (2013) ("The DSU underscores that the purpose of the dispute settlement mechanism is to resolve disputes, not necessarily to effect compliance with trade rules.").

173. Robert D. Putnam, Diplomacy and Domestic Politics: The Logic of Two-Level Games, 42 INT'L ORG. 427 (1988). 
years. ${ }^{174}$ When bargaining with the Brazilian government, the Executive could credibly state that Congress was unlikely to revisit the issue of cotton subsidies before the "farm bill" came up for another vote, and in the short term, Brazil should accept a compromise solution that allowed American cotton subsidies to continue. The Brazilian government would have preferred the elimination of U.S. subsidy payments, but was willing to accept the compromise given the domestic bargaining constraint the Executive faced. ${ }^{175}$

As the United States's legislative inflexibility on trade issues becomes common knowledge, states may expect that compliance will be slow or not forthcoming, and may therefore be deterred from bringing complaints. A state's willingness to bring a complaint in the WTO dispute resolution system depends on a number of factors, including the political relationship between the states, the costs of adjudication, and the expected benefits of a successful suit. ${ }^{176}$ In a suit against the United States, an issue that requires legislative action is likely to yield fewer benefits from a successful suit than an issue that requires executive action to cure. It may also result in higher litigation costs if the United States undertakes more appeals in these cases to delay the application of retaliatory measures. At the margin, these higher costs and lower benefits may lead some states to decide against filing certain WTO claims.

This increase in bargaining power due to congressional reluctance to comply with WTO decisions is not costless. When engaging in trade negotiations, other WTO members may discount the value of American concessions because they anticipate that these concessions may be difficult to enforce. ${ }^{177}$ Consequently, the United States may lose bargaining power in trade discussions because it is unable to commit Congress to complying with WTO decisions ex post. In WTO or regional trade negotiations, the United States may have to offer greater concessions on issues that require congressional involvement than on issues that the executive controls.

In sum, understanding compliance with international law requires attention to the demand side and the supply side of policymaking. Much of the work of compliance may lie in domestic structures-the statutory system and the level of policy discretion allocated to the Executive-as much as in the design of international treaty regimes. Thus far, scholars have focused overwhelmingly on the demands for compliance without sufficiently appreciating the role of national actors in supplying compliance. This Article demonstrates that the supply of compliance is of critical importance to international law and international relations theory. Domestic factors are not only relevant, but can be the most important element in explaining a state's actions on the international stage.

174. Cf. Chana Joffe-Walt, Why U.S. Taxpayers Started-And Stopped-Paying Brazilian Cotton Farmers, NAT'L PUB. RADIO: PLANET MONEY (Jan. 17, 2014), http://www.npr.org/blogs/money/2014 /01/17/263101422/why-u-s-taxpayers-started-and-stopped-paying-brazilian-cotton-farmers.

175. Id.

176. See, e.g., Davis \& Bermeo, supra note 43 .

177. See GuZMAN, supra note 48 , at 35 . 
APPENDIX A

SUMMARY STATISTICS FOR INDEPENDENT VARIABLES

\begin{tabular}{lllll}
\hline Variable & Mean & SD & Min & Max \\
\hline US Domestic & & & & \\
$\begin{array}{l}\text { Congress } \\
\text { Required }\end{array}$ & 0.19 & 0.40 & 0 & 1 \\
$\begin{array}{l}\text { Divided } \\
\text { Government }\end{array}$ & 0.73 & 0.45 & 0 & 1 \\
\hline $\begin{array}{l}\text { Relationship } \\
\begin{array}{l}\text { USA Exports } \\
\text { (ln) }\end{array}\end{array}$ & 10.39 & 1.95 & 4.85 & 13.30 \\
$\begin{array}{l}\text { Formal } \\
\text { Alliance }\end{array}$ & 0.70 & 0.46 & 0 & 1 \\
\hline & & & & \\
\hline
\end{tabular}

\section{Complainant}

$\begin{array}{lllll}\text { GDP Per } & 9.23 & 1.31 & 6.01 & 12.02\end{array}$

Capita (ln)

$\begin{array}{lllll}\text { Population } & 18.95 & 1.99 & 11.31 & 21.57\end{array}$

(ln)

Polity Score

6.81

5.15

$-7$

10

\section{Dispute}

$\begin{array}{lcccc}\begin{array}{l}\text { Trade } \\ \text { Remedy Case }\end{array} & 0.68 & 0.47 & 0 & 1 \\ \text { Contributions } & 18.78 & 0.64 & 17.62 & 19.86\end{array}$

(ln) 


\section{APPENDIX B}

REGRESSION RESULTS

APPENDIX B.1: REGRESSION RESULTS FOR FIGURE 1

\begin{tabular}{|c|c|c|c|}
\hline & $\begin{array}{l}\text { Model } 1 \\
\text { Compliance } \\
\end{array}$ & $\begin{array}{l}\text { Model } 2 \\
\text { Compliance }\end{array}$ & $\begin{array}{l}\text { Model } 3 \\
\text { Compliance } \\
\end{array}$ \\
\hline \multirow[t]{2}{*}{ Congress Required } & $1.93^{*}$ & $3.30^{*}$ & $3.94^{*}$ \\
\hline & $(0.93)$ & $(1.59)$ & $(1.95)$ \\
\hline \multirow[t]{2}{*}{ Divided Government } & & -2.08 & -2.45 \\
\hline & & (1.13) & (1.29) \\
\hline \multirow[t]{2}{*}{ Formal Alliance } & & 5.10 & 5.04 \\
\hline & & $(3.77)$ & $(3.76)$ \\
\hline \multirow[t]{2}{*}{ USA Exports } & & 0.63 & 0.53 \\
\hline & & $(0.64)$ & $(0.74)$ \\
\hline \multirow[t]{2}{*}{ GDP Per Capita } & & -0.44 & -0.34 \\
\hline & & $(0.73)$ & $(0.74)$ \\
\hline \multirow[t]{2}{*}{ Population } & & -0.26 & -0.16 \\
\hline & & $(0.51)$ & $(0.53)$ \\
\hline \multirow[t]{2}{*}{ Polity Score } & & -0.37 & -0.37 \\
\hline & & $(0.25)$ & $(0.25)$ \\
\hline \multirow[t]{2}{*}{ Trade Remedy Case } & & 1.76 & 2.42 \\
\hline & & $(1.49)$ & $(1.84)$ \\
\hline \multirow[t]{2}{*}{ Contributions } & & & -0.72 \\
\hline & & & $(1.07)$ \\
\hline \multirow[t]{2}{*}{ Intercept } & $-1.01^{*}$ & -0.43 & 11.05 \\
\hline & $(0.41)$ & $(7.87)$ & $(18.70)$ \\
\hline$N$ & 37 & 37 & 37 \\
\hline$A I C$ & 47.17 & 47.73 & 49.27 \\
\hline
\end{tabular}

- Standard errors are in parentheses.

${ }^{*}=\mathrm{p}<0.05 ; * *=\mathrm{p}<0.01 ; * * *=\mathrm{p}<0.001$ 
APPENDIX B.2: REGRESSION RESULTS FOR FIGURE 2

\begin{tabular}{|c|c|c|c|}
\hline & $\begin{array}{l}\text { Model } 1 \\
\text { Total Time } \\
\end{array}$ & $\begin{array}{l}\text { Model } 2 \\
\text { Total Time } \\
\end{array}$ & $\begin{array}{l}\text { Model } 3 \\
\text { Total Time } \\
\end{array}$ \\
\hline \multirow[t]{2}{*}{ Congress Required } & $0.23^{* *}$ & $0.06 * * *$ & $0.06^{* *}$ \\
\hline & $(0.50)$ & $(0.79)$ & $(0.86)$ \\
\hline \multirow[t]{2}{*}{ Divided Government } & & $2.89 *$ & 2.82 \\
\hline & & $(0.52)$ & $(0.54)$ \\
\hline \multirow[t]{2}{*}{ Formal Alliance } & & $0.23^{*}$ & $0.24^{*}$ \\
\hline & & $(0.63)$ & $(0.65)$ \\
\hline \multirow[t]{2}{*}{ USA Exports } & & 0.74 & 0.73 \\
\hline & & $(0.28)$ & $(0.29)$ \\
\hline \multirow[t]{2}{*}{ GDP Per Capita } & & 1.28 & 1.29 \\
\hline & & $(0.37)$ & $(0.37)$ \\
\hline \multirow[t]{2}{*}{ Population } & & 1.21 & 1.23 \\
\hline & & $(0.20)$ & $(0.22)$ \\
\hline \multirow[t]{2}{*}{ Polity Score } & & 1.05 & 1.05 \\
\hline & & $(0.06)$ & $(0.06)$ \\
\hline \multirow[t]{2}{*}{ Trade Remedy Case } & & 0.32 & 0.34 \\
\hline & & $(0.67)$ & $(0.75)$ \\
\hline \multirow[t]{2}{*}{ Contributions } & & & 0.94 \\
\hline & & & $(0.41)$ \\
\hline $\mathrm{N}$ & 37 & 37 & 37 \\
\hline R-Squared & 0.26 & 0.55 & 0.55 \\
\hline
\end{tabular}

- Standard errors are in parentheses.

$\mathrm{L}^{*}=\mathrm{p}<0.05{ }^{* *}=\mathrm{p}<0.01 ; * * *=\mathrm{p}<0.001$ 


\section{APPENDIX C}

For simplicity, we will refer to WTO disputes by their dispute number assigned by the WTO. For a complete list of WTO Disputes in chronological order, see Chronological List of Disputes Cases, WORLD TRADE ORG., http://www.wto.org/english/tratop_e/dispu_e/dispu_status_e.htm (last visited Apr. 19, 2014).

Sources for U.S. Compliance Time

\begin{tabular}{|c|c|c|c|c|}
\hline DS\# & $\begin{array}{l}\text { Request } \\
\text { Date }\end{array}$ & $\begin{array}{l}\text { Comply } \\
\text { Date }\end{array}$ & WTO Source & U.S. Gov. Source \\
\hline $\begin{array}{l}\text { DS002, } \\
\text { DSO04 }\end{array}$ & $1 / 24 / 95$ & $8 / 19 / 97$ & $\begin{array}{l}\text { DSB Meeting } \\
\text { Minutes } 25 \\
\text { September } 1997\end{array}$ & $\mathrm{NA}$ \\
\hline DS024 & $12 / 22 / 95$ & $3 / 28 / 97$ & $\begin{array}{l}\text { DSB Meeting } 10 \\
\text { April } 1997\end{array}$ & $\mathrm{NA}$ \\
\hline DS033 & $3 / 14 / 96$ & $12 / 4 / 96$ & $\begin{array}{l}\text { WTO Panel Report } \\
6 \text { January } 1997\end{array}$ & $\begin{array}{l}61 \text { Fed. Reg. } \\
64342\end{array}$ \\
\hline $\begin{array}{l}\text { DS058, } \\
\text { DS061 }\end{array}$ & $10 / 8 / 96$ & $7 / 8 / 99$ & $\begin{array}{l}\text { WTO Appellate } \\
\text { Body Report } 22 \\
\text { October } 2001\end{array}$ & $\begin{array}{l}64 \text { Fed. Reg. } \\
36946\end{array}$ \\
\hline DS099 & $8 / 14 / 97$ & $10 / 20 / 00$ & $\begin{array}{l}\text { WTO Panel Report } \\
7 \text { November } 2000\end{array}$ & $\begin{array}{l}65 \text { Fed. Reg. } \\
59391\end{array}$ \\
\hline DS108 & $11 / 18 / 97$ & $5 / 11 / 06$ & $\begin{array}{l}\text { DSB Meeting } \\
\text { Minutes } 17 \text { May } \\
2006\end{array}$ & $\begin{array}{l}\text { Public Law 109- } \\
222\end{array}$ \\
\hline $\begin{array}{l}\text { DS136, } \\
\text { DS162 }\end{array}$ & $6 / 4 / 98$ & $12 / 3 / 04$ & $\begin{array}{l}\text { DSB Meeting } \\
\text { Minutes } 17 \\
\text { December } 2004\end{array}$ & $\begin{array}{l}\text { Public Law 108- } \\
429\end{array}$ \\
\hline DS138 & $6 / 12 / 98$ & $3 / 14 / 00$ & $\begin{array}{l}\text { DSB Meeting } \\
\text { Minutes } 5 \text { July } \\
2000\end{array}$ & $\begin{array}{l}65 \text { Fed. Reg. } \\
13713\end{array}$ \\
\hline $\mathrm{DS} 160$ & $1 / 26 / 99$ & $4 / 12 / 03$ & $\mathrm{NA}$ & $\begin{array}{l}\text { H.Rept. } 108-77 \text { at } \\
33 \text {. }\end{array}$ \\
\hline DS165 & $3 / 4 / 99$ & $3 / 3 / 99$ & $\begin{array}{l}\text { WTO Appellate } \\
\text { Body Report } 11 \\
\text { December } 2000\end{array}$ & $\begin{array}{l}\text { March 4, } 1999 \\
\text { Letter Director, } \\
\text { Trade Compliance } \\
\text { Division }\end{array}$ \\
\hline DS166 & $3 / 17 / 99$ & $4 / 9 / 01$ & $\begin{array}{l}\text { Statement by the } \\
\text { US and EU } 10 \\
\text { April } 2001\end{array}$ & $\begin{array}{l}66 \text { Fed. Red. } \\
18510\end{array}$ \\
\hline
\end{tabular}




\begin{tabular}{|c|c|c|c|c|}
\hline DS176 & $7 / 8 / 99$ & & NA & $\begin{array}{l}\text { CRS Report } \\
\text { RL32014 }\end{array}$ \\
\hline $\begin{array}{l}\text { DS177, } \\
\text { DS178 }\end{array}$ & $7 / 16 / 99$ & $11 / 14 / 01$ & $\begin{array}{l}\text { DSB Meeting } \\
\text { Minutes } 21 \\
\text { November } 2001\end{array}$ & Proclamation 7502 \\
\hline DS179 & $7 / 30 / 99$ & $8 / 28 / 01$ & $\begin{array}{l}\text { DSB Meeting } \\
\text { Minutes } 10 \\
\text { September } 2001\end{array}$ & $\begin{array}{l}66 \text { Fed. Reg. } \\
45278\end{array}$ \\
\hline DS184 & $11 / 18 / 99$ & $11 / 8 / 02$ & NA & $\begin{array}{l}67 \text { Fed. Reg. } \\
69186\end{array}$ \\
\hline DS192 & $4 / 3 / 00$ & $11 / 9 / 01$ & $\begin{array}{l}\text { DSB Meeting } \\
\text { Minutes } 21 \\
\text { November } 2001\end{array}$ & $\begin{array}{l}66 \text { Fed. Reg. } \\
56805\end{array}$ \\
\hline DS202 & $6 / 13 / 00$ & $3 / 1 / 03$ & $\begin{array}{l}\text { DSB Meeting } \\
\text { Minutes } 19 \text { June } \\
2006\end{array}$ & $\begin{array}{l}68 \text { Fed. Reg. } \\
19578\end{array}$ \\
\hline DS212 & $11 / 10 / 00$ & $5 / 26 / 06$ & $\begin{array}{l}\text { DSB Meeting } \\
\text { Minutes } 18 \text { March } \\
2003\end{array}$ & 72 Fed. Reg. 6519 \\
\hline DS213 & $11 / 10 / 00$ & $4 / 1 / 04$ & $\begin{array}{l}\text { DSB Meeting } \\
\text { Minutes } 20 \text { April } \\
2004\end{array}$ & $\begin{array}{l}69 \text { Fed. Reg. } \\
17,131\end{array}$ \\
\hline $\begin{array}{l}\text { DS217, } \\
\text { DS234 }\end{array}$ & $12 / 21 / 00$ & $2 / 8 / 06$ & NA & $\begin{array}{l}\text { Public Law 109- } \\
171 \text {, Sec. } 7601\end{array}$ \\
\hline
\end{tabular}

\begin{tabular}{|c|c|c|c|c|}
\hline $\begin{array}{l}\text { DS236, } \\
\text { DS247, } \\
\text { DS257, } \\
\text { DS264, } \\
\text { DS277, } \\
\text { DS311 }\end{array}$ & $8 / 21 / 01$ & $9 / 12 / 06$ & $\begin{array}{l}\text { Statement By US } \\
\text { and Canada } 12 \\
\text { October } 2006\end{array}$ & $\begin{array}{l}\text { Comprehensive } \\
\text { Agreement } 12 \\
\text { September } 2006\end{array}$ \\
\hline $\begin{array}{l}\text { DS248, } \\
\text { DS249, } \\
\text { DS251, } \\
\text { DS252, } \\
\text { DS253, } \\
\text { DS254, } \\
\text { DS258, } \\
\text { DS259 }\end{array}$ & $3 / 7 / 02$ & $12 / 4 / 03$ & $\begin{array}{l}\text { DSB Meeting } \\
\text { Minutes } 10 \\
\text { December } 2003\end{array}$ & Proclamation 7741 \\
\hline
\end{tabular}




\begin{tabular}{|c|c|c|c|c|}
\hline DS267 & $9 / 27 / 02$ & $4 / 6 / 10$ & $\begin{array}{l}\text { Statement by the } \\
\text { US and Brazil } 25 \\
\text { August } 2010\end{array}$ & $\begin{array}{l}\text { USTR Press } \\
\text { Release (April 6, } \\
\text { 2010); Public Law } \\
\text { 112-55 }\end{array}$ \\
\hline DS268 & $10 / 7 / 02$ & $6 / 22 / 07$ & $\begin{array}{l}\text { DSB Meeting } \\
\text { Minutes } 31 \text { August } \\
2007\end{array}$ & $\begin{array}{l}72 \text { Fed. Reg. } \\
34442\end{array}$ \\
\hline DS285 & $3 / 13 / 03$ & & NA & $\begin{array}{l}\text { CRS Report } \\
\text { RL32014 }\end{array}$ \\
\hline DS294 & $6 / 12 / 03$ & $6 / 20 / 12$ & NA & $\begin{array}{l}77 \text { Fed. Reg. } \\
\text { 29875; USTR } \\
\text { Press Release } \\
\text { (February 6, 2012) }\end{array}$ \\
\hline DS322 & $11 / 24 / 04$ & $6 / 20 / 12$ & NA & $\begin{array}{l}77 \text { Fed. Reg. } \\
\text { 29875; USTR } \\
\text { Press Release } \\
\text { (February 6, 2012) }\end{array}$ \\
\hline DS335 & $11 / 17 / 05$ & $8 / 15 / 07$ & $\begin{array}{l}\text { DSB Meeting } \\
\text { Minutes } 31 \text { August } \\
2007\end{array}$ & $\begin{array}{l}72 \text { Fed. Reg. } \\
48257\end{array}$ \\
\hline $\begin{array}{l}\text { DS343, } \\
\text { DS345 }\end{array}$ & $4 / 24 / 06$ & $4 / 1 / 09$ & $\begin{array}{l}\text { DSB Meeting } \\
\text { Minutes } 20 \text { April } \\
2009\end{array}$ & $\begin{array}{l}74 \text { Fed. Reg. } \\
14809\end{array}$ \\
\hline DS344 & $5 / 26 / 06$ & $6 / 20 / 12$ & NA & $\begin{array}{l}77 \text { Fed. Reg. } \\
\text { 29875; USTR } \\
\text { Press Release } \\
\text { (February 6, 2012) }\end{array}$ \\
\hline DS350 & $10 / 2 / 06$ & $6 / 20 / 12$ & NA & $\begin{array}{l}77 \text { Fed. Reg. } \\
\text { 29875; USTR } \\
\text { Press Release } \\
\text { (February 6, 2012) }\end{array}$ \\
\hline DS379 & $11 / 19 / 08$ & & NA & $\begin{array}{l}\text { CRS Report } \\
\text { RL32014 }\end{array}$ \\
\hline DS382 & $11 / 27 / 08$ & $4 / 16 / 12$ & NA & $\begin{array}{l}77 \text { Fed. Reg. } \\
23659 \text {; USITC } \\
4311\end{array}$ \\
\hline DS383 & $11 / 26 / 08$ & $7 / 28 / 10$ & $\begin{array}{l}\text { DSB Meeting } \\
\text { Minutes } 31 \text { August } \\
2010\end{array}$ & $\begin{array}{l}75 \text { Fed. Reg. } \\
48940\end{array}$ \\
\hline
\end{tabular}




\begin{tabular}{lcrll}
\hline DS392 & $4 / 17 / 09$ & $9 / 30 / 09$ & $\begin{array}{l}\text { WTO Panel Report } \\
\text { 20 September } \\
2010\end{array}$ & NA \\
& & & WTO & 76 Fed. Reg. \\
DS402 & $11 / 24 / 09$ & $10 / 24 / 11$ & $\begin{array}{l}\text { WTO } \\
\text { Communique } 9\end{array}$ & 66892 \\
& & & December 2011 & \\
\hline DS404 & $2 / 1 / 10$ & $4 / 16 / 12$ & $\begin{array}{l}\text { Statement by the } \\
\text { US 24 May 2012 }\end{array}$ & 77 Fed. Reg. 8101 \\
& & & \\
\hline
\end{tabular}

